OPEN ACCESS

Edited by:

Heidi Noels,

RWTH Aachen University, Germany

Jürgen Bernhagen,

RWTH Aachen University, Germany

Reviewed by:

Rafael Franco,

University of Barcelona, Spain

Catherine Anne Abbott,

Flinders University, Australia

Mark Gorrell,

University of Sydney, Australia

*Correspondence:

Ingrid De Meester,

Laboratory of Medical Biochemistry,

Department of Pharmaceutical

Sciences, University of Antwerp,

Universiteitsplein 1 ,

Antwerp 2610, Belgium

ingrid.demeester@uantwerpen.be

Specialty section:

This article was submitted to Chemoattractants, a section of the journal Frontiers in Immunology

Received: 21 April 2015

Accepted: 13 July 2015

Published: 07 August 2015

Citation:

Waumans Y, Baerts L, Kehoe K, Lambeir A-M and De Meester I (2015) The dipeptidyl peptidase family, prolyl oligopeptidase, and

prolyl carboxypeptidase in the immune system and inflammatory disease, including atherosclerosis.

Front. Immunol. 6:387. doi: 10.3389/fimmu.2015.00387

\section{The dipeptidyl peptidase family, prolyl oligopeptidase, and prolyl carboxypeptidase in the immune system and inflammatory disease, including atherosclerosis}

\author{
Yannick Waumans, Lesley Baerts, Kaat Kehoe, Anne-Marie Lambeir and \\ Ingrid De Meester*
}

Laboratory of Medical Biochemistry, Department of Pharmaceutical Sciences, University of Antwerp, Antwerp, Belgium

Research from over the past 20 years has implicated dipeptidyl peptidase (DPP) IV and its family members in many processes and different pathologies of the immune system. Most research has been focused on either DPPIV or just a few of its family members. It is, however, essential to consider the entire DPP family when discussing any one of its members. There is a substantial overlap between family members in their substrate specificity, inhibitors, and functions. In this review, we provide a comprehensive discussion on the role of prolyl-specific peptidases DPPIV, FAP, DPP8, DPP9, dipeptidyl peptidase II, prolyl carboxypeptidase, and prolyl oligopeptidase in the immune system and its diseases. We highlight possible therapeutic targets for the prevention and treatment of atherosclerosis, a condition that lies at the frontier between inflammation and cardiovascular disease.

Keywords: dipeptidyl peptidase, prolyl oligopeptidase, fibroblast activation protein $\alpha$, prolyl carboxypeptidase, inflammation, immunophysiology, atherosclerosis

\section{Introduction}

Research from over the past 20 years has implicated the dipeptidyl peptidase (DPP) family in various physiological processes and pathologies of the immune system. Usually only four prolyl-specific peptidases are considered: DPPIV (EC 3.4.14.5), fibroblast activation protein $\alpha$ (FAP; EC 3.4.21.B28), and the more recently discovered DPP8 and DPP9 (EC 3.4.14). However, due to similarities in substrate specificity and structural homology, it is more relevant to consider a broader family that also includes prolyl oligopeptidase (PREP; EC 3.4.21.26), dipeptidyl peptidase II (DPPII) (EC 3.4.14.2), and prolyl carboxypeptidase (PRCP; EC 3.4.16.2). First, DPPII and PRCP share the $\alpha / \beta$ hydrolase fold with the other DPPs and the catalytic triad is completely conserved in both enzymes (2). Moreover, DPPII can cleave several DPPIV substrates in vitro (3). Conversely, due to its substrate preference for tripeptides (4), DPPII could actually be considered as a prolyl carboxytripeptidase, emphasizing its similarities to PRCP. Another argument for considering a broader family stems from the fact that functional studies on the role of peptidases rely heavily on the use of enzyme inhibitors and many of the inhibitors used in earlier studies are now known to inhibit more than one family member. For example, early studies on DPPIV used inhibitors which we now know also inhibit DPPII, DPP8, DPP9, FAP, and/or PREP due to their sequential and/or structural similarity [e.g., Ref. (5-9)]. PRCP is known to be inhibited by KYP-2047 and Z-Pro-Prolinal at higher concentrations, 
which have often been used for the functional study of PREP [e.g., Ref. (10-12)]. Table 1 summarizes the most commonly used DPP inhibitors and their selectivity compared to DPPIV. In view of the aforementioned reasons and for the sake of simplicity, we will use "DPP family" as a blanket term, which includes DPPII, PRCP, and PREP even though strictly speaking they are not DPPs. Figure 1 provides a general overview of this broadly defined DPP family. The roles of various family

TABLE 1 | Overview of commonly used inhibitors within the DPP family and the ratio of inhibitor needed to inhibit the respective DPP family member compared to what is needed to inhibit DPPIV.

\begin{tabular}{|c|c|c|c|c|c|c|c|c|}
\hline Inhibitors & & DPPII & DPP8 & DPP9 & FAP & PREP & PRCP & Reference \\
\hline \multirow[t]{6}{*}{ Clinical } & Alogliptin & $>14,000$ & $>14,000$ & $>14,000$ & $>14,000$ & $>14,000$ & ND & (16) \\
\hline & Linagliptin & $>100,000$ & 40,000 & $>10,000$ & 89 & $>100,000$ & ND & (17) \\
\hline & Saxagliptin & $>50,000$ & 390 & 77 & $>4,000$ & ND & ND & (18) \\
\hline & Sitagliptin & $>5,550$ & $>5,550$ & $>2,660$ & $>5,550$ & $>5,550$ & ND & (19) \\
\hline & Talabostat & 4 & 8 & 4 & 3 & 44 & ND & \\
\hline & Vildagliptin & $>100,000$ & 270 & 32 & 285 & 60,000 & ND & $(20,21)$ \\
\hline \multirow[t]{5}{*}{ Experimental } & $1 G 244$ & 1 & $<10^{-3}$ & $<10^{-3}$ & 1 & ND & ND & (21) \\
\hline & KYP2047 & 1 & ND & 1 & 1 & $<10^{-4}$ & 1 & $(12,22)$ \\
\hline & UAMC01110 & 1 & ND & 0.5 & $<10^{-4}$ & 0.1 & ND & (23) \\
\hline & UAMC00039 & $<10^{-5}$ & 1 & 2 & $>10$ & ND & ND & $(24,25)$ \\
\hline & Z-Pro-Prolinal & ND & ND & ND & ND & $<10^{-2}$ & * & $(26,27)$ \\
\hline
\end{tabular}

Partly adapted from Deacon (28).

*Z-Pro-Prolinal is currently used as an inhibitor for PRCP although it is in vitro $10^{3}$ times more selective toward PREP.

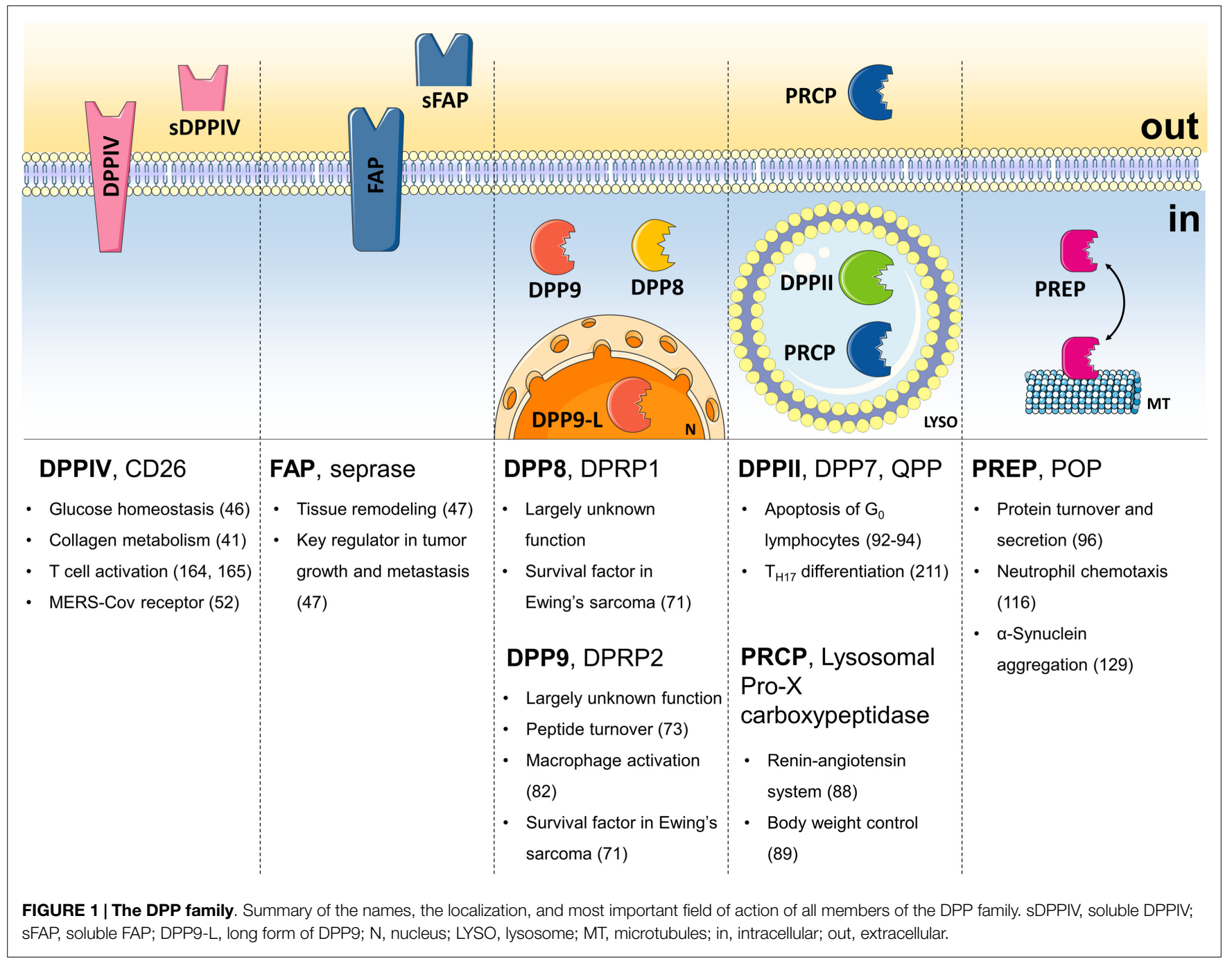


members in certain aspects of the immune system or immune dysfunction have been reviewed in the past [e.g., Ref. (1315)]. In this review, we provide a comprehensive discussion and update on the roles of DPPIV, DPPII, DPP8, DPP9, FAP, PREP, and PRCP in the immune system and inflammatory disease. We highlight the role of these enzymes in atherosclerosis, a condition that lies at the frontier between inflammation and cardiovascular disease, as the DPP family encompasses possible therapeutic targets for the prevention and treatment of this disease.

\section{A Brief Guide to the DPP Family}

\section{Dipeptidyl Peptidase IV}

The prototypical DPP, DPPIV (often DPP4 in medical jargon) cleaves off an $\mathrm{N}$-terminal dipeptide from peptides with Pro or Ala on the penultimate position. Its localization as a soluble enzyme in body fluids, or anchored in the plasma membrane of cells provides it with the necessary access to cleave a wide range of bioactive peptides. As such, it can modify their biological activity. Glucagon-like peptide (GLP)-1 and -2, and glucosedependent insulinotropic peptide (GIP) $(29,30)$, substance P (31), neuropeptide Y (NPY) (32), stromal cell-derived factor$1 \alpha / \beta$ (SDF-1 $\alpha / \beta$ or CXCL12) (33), granulocyte macrophage colony-stimulating factor (GM-CSF) (1), CXCL10 (34-36), and high-mobility group box 1 (HMGB1) (37) have been identified as physiological substrates, while others, such as RANTES, have been proposed based on in vitro experiments [e.g., Ref. (38)]. DPPIV also performs many of its physiological functions through interactions with other proteins, such as collagen, fibronectin, adenosine deaminase (ADA), caveolin-1, and the mannose-6-phosphate/insulin-like growth factor II receptor (M6P/IGFIIR) (39-41). Some of those will be discussed in more detail below.

Dipeptidyl peptidase IV is well known for its role in glucose homeostasis. It has become a validated therapeutic target for the treatment of type 2 diabetes (T2D) (46). DPPIV inhibitors reduce the rate of GLP-1 inactivation (Boxes 1 and 2). It has also been shown to be involved in cancer biology. The role of the DPP family in cancer has been addressed in several other reviews $(39,47-51)$. Finally, DPPIV has recently come back into the center of attention as the receptor for the MERS coronavirus (52).

BOX 1 | Incretins.

The incretins are a group of glucose-lowering molecules produced by the intestines. The best known incretin is glucagon-like peptide-1 (GLP-1). This incretin is derived from proglucagon and secreted after a meal from L-cells in the distal ileum and colon. In the pancreas, it induces insulin secretion and biosynthesis while lowering glucagon secretion. In addition, GLP-1 increases the $\beta$-cell mass, thereby restoring insulin production. It is clear that GLP-1 also has functions outside glucose metabolism. Its receptor, GLP-1-R, is not only found in the pancreas but also expressed in brain, lung, kidney, stomach, and heart $(42,43)$. Recently, it was shown that stimulation after myocardial infarction reduces the infarct size $(44,45)$. Currently, GLP-1 agonists are approved for the treatment of type 2 diabetes. These incretin mimetics seem to have a slightly better efficacy as DPPIV inhibitors and lead more frequently to weight loss. Unfortunately, an important drawback for their therapeutic use is that they can only be administered by subcutaneous injection (46).

\section{Fibroblast Activation Protein $\alpha$}

Fibroblast activation protein $\alpha$, also known as seprase can present itself as a type II transmembrane protein or as a shedded plasma protease (57). In the latter case, it is also known as antiplasmincleaving enzyme, which converts $\alpha 2$-antiplasmin into a more active form, suppressing fibrinolysis (58). Some of the known DPPIV substrates were later found to be cleaved in vitro by FAP as well (59), though any physiological relevance remains unclear.

Unlike DPPIV, FAP also possesses a gelatinase activity. This enables FAP to degrade proteins of the extracellular matrix (60). This is of particular interest with regard to its involvement in a number of pathological processes (47). FAP is highly induced during inflammation, activation of hepatic stellate cells in liver cirrhosis and strongly expressed by mesenchymal cells of remodeling tissue $(47,61)$. FAP is also a key regulator during tumor growth and metastasis (47). As all these processes require degradation of the extracellular matrix, FAP's involvement in these pathologies is most likely associated with its gelatinase activity (51). Its role in cancer biology has been reviewed before $(47,62)$. It is interesting to note that, so far, in clinical trials Talabostat has shown minimal or no clinical benefit for the treatment of metastatic colorectal cancer, advanced non-small cell lung cancer, or stage IV melanoma (63-65). It should be mentioned, however, that Talabostat is a broad-range inhibitor also targeting DPPIV, DPP8, and DPP9.

\section{Dipeptidyl Peptidases 8 and 9}

Dipeptidyl peptidases 8 and DPP9 show DPPIV-like activity and share a very high-sequence similarity to each other (77\% aa similarity, $57 \%$ aa identity) (24). These cytoplasmic enzymes have several isoforms. It has been a matter of debate whether all are expressed as protein in cells and, if so, whether they are active (66-69). Interestingly, the $\mathrm{N}$-terminal extension of the longer DPP9 variant contains a nuclear localization signal and, indeed, this form localizes to the nucleus (69). DPP8 has been shown to cleave a number of DPPIV chemokine substrates in vitro (70). Another DPPIV substrate, NPY, has indirectly been shown to be

\section{BOX 2 | DPPIV inhibitors.}

Dipeptidyl peptidase IV inhibitors prolong the biological half-life of the incretins and are therefore used for the treatment of type 2 diabetes. Sitagliptin, vildagliptin, saxagliptin, linagliptin, and alogliptin are DPPIV inhibitors currently available on the market for treatment of type 2 diabetes. Sitagliptin and alogliptin are highly selective toward DPPIV in vitro, whereas vildagliptin and saxagliptin are less selective with regard to DPP8 and 9, and linagliptin with regard to FAP (28). Their clinical efficacy and safety in the use of type 2 diabetes seem comparable as far as can be judged from the data available.

There is a growing interest toward a use outside type 2 diabetes as it has become clear that DPPIV inhibitors have pleiotropic effects. While negative effects have been found in heart failure (53), some studies suggest them as a possible therapeutic strategy in cardiovascular pathologies $(28,54)$. The SITAGRAMI trial and follow-up studies revealed that the combination of a DPPIV inhibitor with granulocyte-colony-stimulating factor or in monotherapy presents a therapeutic option after myocardial infarction $(55,56)$. As stated above, the mechanism is not yet clear but may be explained by a longer biological half-life of DPPIV substrates, glucagon-like peptide-1, B-type natriuretic peptide, and stromal cell-derived factor $-1 \alpha / \beta$. All three peptides have a cardioprotective effect that is abolished by DPPIV-mediated cleavage. For an extensive review of the involved substrates, see Matheeussen et al. (43). 
a DPP8 and DPP9 substrate as well (71). Efforts have been made to find intracellular DPP8 and 9 substrates using a peptidomic approach (72), but so far it has been hard to attribute physiological relevance to the possible substrates beyond the role of DPP8 and 9 in intracellular peptide turnover (73).

The physiological functions of DPP8 and DPP9 are still not properly understood. Mainly, a lack of available knockout animals, specific inhibitors, and substrates has hampered progress (24). A mouse model has been established with a targeted inactivation of DPP9 enzymatic activity (74), but homozygous DPP9inactive neonates die within 8-24h after birth. Despite these limitations, some indications toward their role are surfacing. Using immunohistochemistry, DPP8 and 9 were found associated with spermatozoids and spermatids and the short mRNA of DPP8 is predominantly expressed in testes $(75,76)$, suggesting a role in spermatogenesis and male fertility. Recent work has found SUMO1 to be an allosteric activator of DPP9 (77), whereas a small peptide corresponding to the interaction surface of SUMO1 is a non-competitive inhibitor of DPP8 and DPP9 (78). A genomewide association study has linked DPP9 to idiopathic pulmonary fibrosis (79).

Finally, a number of studies have shown a role for DPP8 and DPP9 in apoptosis $(71,80-83)$. Two studies showed that overexpression enhanced induced apoptosis and impaired cell adhesion and migration $(80,81)$. Conversely, DPP8/9 inhibition in tumor cells decreased the number of viable cells because of a decreased cleavage of pro-apoptotic NPY (71). In macrophages, inhibition caused a marginal, yet significant increase in apoptosis, independent of NPY cleavage (82). Interestingly, vildagliptin, a DPPIV inhibitor already on the market to treat type 2 diabetes, but with poorer selectivity toward DPP8 and 9, was shown to enhance parthenolide's anti-leukemic activity through its inhibition of DPP8 and 9, and not DPPIV (83).

\section{Dipeptidyl Peptidase II and Prolyl Carboxypeptidase}

Prolyl carboxypeptidase, also called angiotensinase $\mathrm{C}$ or lysosomal Pro-X carboxypeptidase, is a lysosomal carboxypeptidase sharing strong sequence homology with the likewise lysosomal DPPII $(4,84)$. PRCP preferentially cleaves off the C-terminal amino acid when Ala or Pro is in the penultimate position, while DPPII targets N-terminal X-Pro or X-Ala dipeptides $(85,86)$. In addition to a structural similarity, PRCP and DPPII have partially overlapping substrate specificities due to DPPII's preference for tripeptide substrates (4). Perhaps surprisingly, Gly-Pro-pNA and Ala-Pro-pNA, two typical synthetic DPP substrates, have actually been used to perform PRCP activity measurements (87).

Prolyl carboxypeptidase is particularly known as one of the key enzymes of the renin-angiotensin system (RAS). It inactivates the vasoactive peptides angiotensin II and angiotensin III by cleaving off the C-terminal Phe (88). $\alpha$-Melanocyt-stimulating hormone 1-13, an anorexigenic neuromodulator, is inactivated by PRCP, implying a role in body weight control (89). Based on the involvement of PRCP in the conversion of these peptide hormones, the enzyme has also been associated with diseases, such as hypertension, diabetes mellitus, obesity, inflammation, and cardiovascular dysfunction $(90,91)$.
Dipeptidyl peptidase II has no known natural substrates. The DPPIV substrate substance $\mathrm{P}$ has been shown to be cleaved by DPPII in vitro (3), but much less efficiently, casting doubt over any physiological relevance. It has been shown that inhibition or silencing of DPPII causes apoptosis of quiescent $G_{0}$ lymphocytes (92-94). On the other hand, a highly specific DPPII inhibitor, UAMC00039, did not induce apoptosis, autophagy, or necrosis in human leukocytes $(25,95)$, but this study did not specifically look at quiescent cells or lymphocytes. Finally, changes in DPPII activity levels have been observed in a number of pathologies, such as neurodegenerative disorders, myopathies, cancer, and gastro-intestinal disorders (4).

\section{Prolyl Oligopeptidase}

Prolyl oligopeptidase is an oligopeptidase with endopeptidase activity. It has been shown to be localized in the cytoplasm (9699), but given its ability to inactivate several neuropeptides in vitro by limited proteolysis (100-115), its involvement in the in vivo generation of immunoactive peptides $N$-acetyl-prolyl-glycylproline and $N$-acetyl-seryl-aspartyl-lysyl-proline $(116,117)$, and its presence in plasma $(118,119)$, it most likely also has an extracellular role.

Initial interest for PREP derived from the positive effects of PREP inhibitors on scopolamine-induced amnesia in rats (120123). PREP inhibition was also found to promote neuronal survival and neurite outgrowth of cerebellar granule cells (124). However, a recent study in mice shows that the lack of PREP in vivo causes a reduction of synaptic spine density in the hippocampal region along with reduced long-term potentiation and memory functions (125).

Many of PREP's functions are mediated through its interactions with other proteins. PREP is known to interact with GAP-43 (126, 127), $\alpha$-tubulin (96), and GADPH (128). Its most studied interaction is with $\alpha$-synuclein (126), reviewed in Ref. (129). PREP and $\alpha$-synuclein have been shown to co-localize in cell models of stress and in the substantia nigra of post-mortem Parkinson's disease brain $(11,130)$. In vitro, the aggregation rate of $\alpha$-synuclein increases in the presence of high concentrations of PREP, which is abolished through active site inhibitors of PREP and absent with a catalytically impaired PREP mutant (131). In vivo, PREP inhibition reduces $\alpha$-synuclein aggregates in a cellular and animal model for Parkinson's disease (11).

\section{The DPP Family in the Immune System}

\section{The DPP Family in the Innate Immune System DPP Family Members in Monocytes and Macrophages}

The role of DPPIV in monocytes and macrophages has been somewhat contested. Whereas DPPIV's presence on monocytes and macrophages has been shown repeatedly in mice and rats (132-134), its expression in human monocytes and macrophages is less obvious. Figure 2 shows an overview of the expression of DPPIV throughout the immune system. In visceral obesity, DPPIV expression is low on peripheral blood monocytes, macrophages, and dendritic cells, but it is upregulated in vitro 


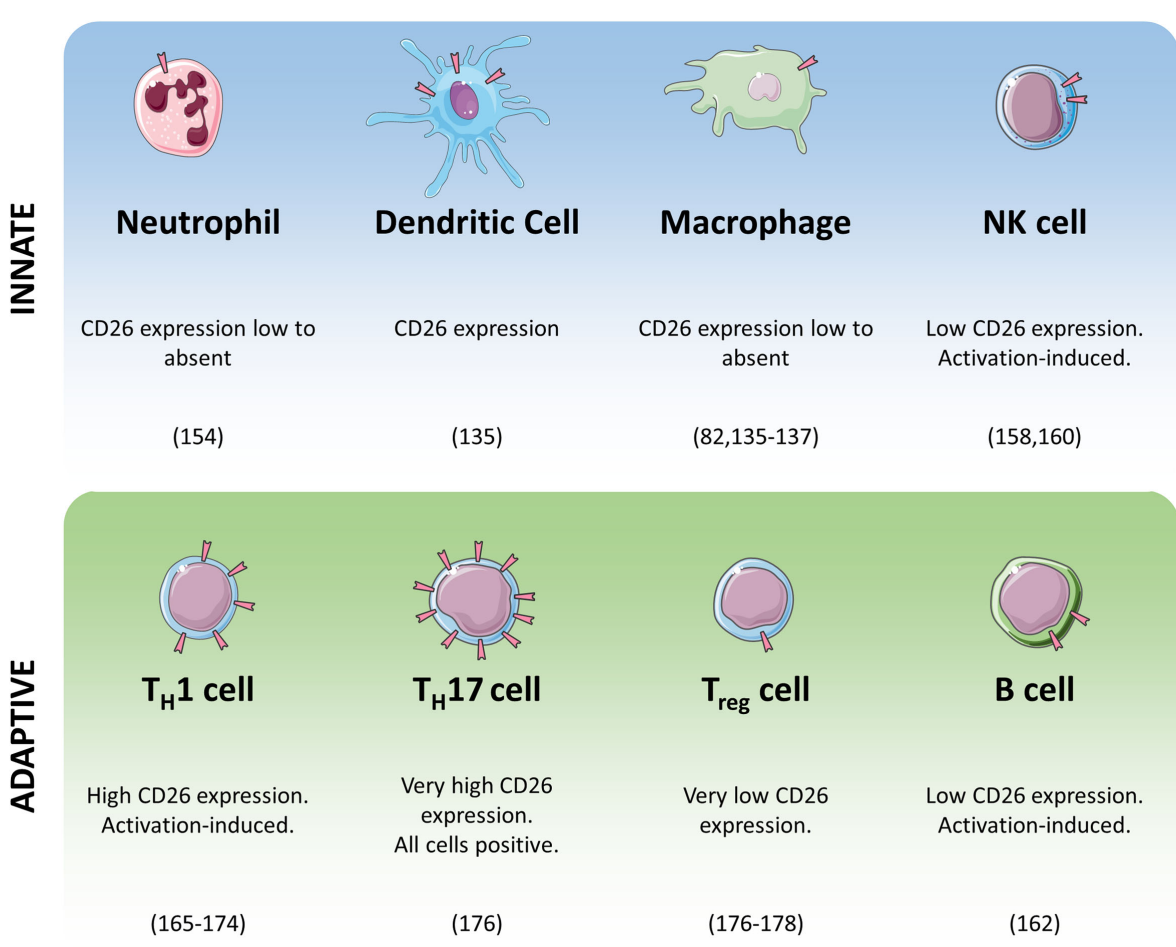

FIGURE 2 | Summary of CD26/DPPIV expression in cells of the immune system

after differentiation and activation of isolated monocytes into macrophages or dendritic cells, and in vivo locally in adipose tissue (135). Interestingly, the authors showed that macrophage- or dendritic cell-associated DPPIV most likely binds ADA, promoting local degradation of adenosine, a T-cell proliferation suppressor, thereby inducing T-cell proliferation (135). Three other studies also found no to low DPPIV expression or activity associated with human monocytes and/or macrophages (82, 136-138). Others have investigated DPPIV in monocyte- or macrophage-like cell lines (136, 137, 139-144). In HL-60 cells, its expression has been found to be regulated by differentiation into macrophage-like cells (139). DPPIV inhibitor alogliptin can affect ERK activation, MMP1 and IL-6 secretion in U937 cells $(140,141)$. However, these studies employed alogliptin at concentrations lower than its $\mathrm{IC}_{50}$ for DPPIV. It is therefore questionable whether the observed effects were mediated by DPPIV at all. On the other hand, proliferation is reduced in the presence of a DPP inhibitor in U937 cells expressing high levels of DPPIV, but not in the same cell type expressing low levels of DPPIV (144). Moreover, the same inhibitor causes the former cells to secrete lower amounts of IL-1 $\beta$, but higher amounts of TNF $\alpha$ (144). It could be that inhibition merely increases TNF $\alpha$ 's half-life, as DPPIV has been implicated in its degradation in U937 cells (137). In THP-1 cells, DPPIV inhibitors alogliptin and sitagliptin both reduced these cells' chemotactic potential (142). DPPIV inhibitors sitagliptin and NVPDPP728 also reduced NLRP3, TLR4, and IL-1 $\beta$ expression and increased GLP-1R expression in THP-1 cells and this effect was blocked through PMA differentiation (143). Importantly, such cell lines have been derived from different types of myeloid leukemia, and as it is known that DPPIV expression is often dysregulated in cancer (47-51), the physiological relevance of these findings remains uncertain. FAP has been shown on tumor-associated macrophages in human breast cancer (145).

Dipeptidyl peptidase $8 / 9$ activity has been found in human monocytes and U937 cells (136). DPP8 was found associated with activated microglia/macrophages in a rat model of cerebral ischemia (146). DPP8 and 9 are abundantly present in macrophage-rich regions of atherosclerotic plaques (82). Interestingly, DPP9 is upregulated after in vitro monocyte-to-macrophage differentiation. Moreover, inhibition or RNA silencing of DPP9 attenuates pro-inflammatory $\mathrm{M} 1$, but not $\mathrm{M} 2$, macrophage activation (82).

In rats, DPPII is expressed in tissue-resident macrophages (147, 148). Humans show DPPII activity in monocytes as well as U937 cells $(25,136)$. Human blood derived alveolar macrophages show high-PRCP activity $(138,149)$. Interestingly, in a mouse in vivo angiogenesis assay, macrophage infiltration into the wound was increased in mice with a PRCP deletion (150).

Prolyl oligopeptidase activity has been shown in mouse and rat peritoneal macrophages and in rat pulmonary macrophages $(134,151,152)$. Its activity in mouse peritoneal macrophages is increased after thioglycollate ellicitation (134). In addition, PREP has been identified as a neurotoxic component in the supernatant of activated THP-1 cells, which are monocyte-like cells (153). Apparently, these cells secrete PREP upon activation with IFN $\gamma$ and LPS and partly because of this, their supernatant is toxic to neuroblastoma SH-SY5Y cells, as shown through the use of PREPspecific inhibitors (153). PREP's mode of action in this remains unclear. 


\section{DPP Family Members in Granulocytes}

Recently, a study showed that DPPIV acts as a chemorepellent for human and murine neutrophils (154). Adding recombinant DPPIV to purified human neutrophils in an Insall chamber causes the neutrophils to migrate away from the higher concentration of DPPIV. This effect is blocked by DPPIV inhibitors, meaning that the effect is mediated through DPPIV's enzymatic activity, although a candidate substrate is not obvious. Moreover, in a mouse model of acute respiratory distress syndrome, oropharyngeal aspiration of DPPIV prevented accumulation of neutrophils in the lung (154). By contrast, PREP is involved in the generation of prolyl-glycyl-proline, a collagen fragment that is an efficient neutrophil chemoattractant (155). Human peripheral blood neutrophils contain PREP activity and are themselves capable of generating prolyl-glycyl-proline after LPS-activation, alluding to a self-sustaining pathway of neutrophil inflammation (116). PRCP is also abundantly expressed in human neutrophils (90).

The recruitment of eosinophils is affected by DPPIV activity. CCL11, also known as eotaxin, is a DPPIV substrate and cleavage by DPPIV prevents the activation of its receptor CCR3 (156). In rats, it was shown that administration of CCL11 results in eosinophil recruitment and this recruitment is significantly more effective in DPPIV-deficient F344 mutants (156).

Finally, DPPII activity has been reported in the granules of mast cells in several publications $(147,148,157)$. It is released from peritoneal mast cells upon degranulation and is apparently inhibited by histamine and $\mathrm{Zn}^{2+}$ at concentrations present in the granules of mast cells (157).

\section{DPP Family Members in Natural Killer Cells}

Dipeptidyl peptidase 4 is present in low amounts on freshly isolated human NK cells and its expression is only upregulated in a small subpopulation after IL-2 stimulation (158). In that study, it was also shown that DPPIV inhibition suppresses DNA synthesis and cell cycle progression of NK cells, but these effects may be DPP8/9 mediated as the inhibitors used in that study are now known to also inhibit DPP8/9 activity (159). Another study shows that DPPIV is actually only expressed by a small subpopulation of peripheral NK cells (160). The natural cytotoxicity of NK cells is not influenced by the presence or absence of DPPIV on their cell surface $(158,160)$. However, DPPIV-negative NK cells show significantly less CD16-dependent lysis than DPPIV-positive NK cells (160). Interestingly, NK cytolytic function against tumor cells was diminished in DPPIV-deficient rats in a model for lung metastasis (161).

Figure 3 shows an overview of published data on the DPP family in the innate immune system.

\section{The DPP Family in the Adaptive Immune Response DPP Family Members in Humoral Immunity}

Only about $5 \%$ of freshly isolated CD20-positive B cells express DPPIV, but this fraction grows significantly upon pokeweed mitogen (PWM) or S. aureus protein stimulation (162). Similar to NK cells, DPPIV inhibitors significantly suppress DNA synthesis in B-lymphocytes (162), but again these inhibitors are now known to also inhibit DPP8 and 9 (159). Mouse spleen-derived
B-lymphocytes only express low amounts of DPPIV mRNA (163). DPP8 and 9 mRNA, on the other hand, are expressed at much greater levels in these cells, and they are upregulated in Raji cells, a B-lymphocyte-like cell line, after PWM, LPS stimulation or mitomycin c treatment, and downregulated after DTT treatment (163). DPP8 and 9 have also been shown immunohistochemically in human lymph follicular lymphocytes (164). DPPII activity has also been shown in human B-lymphocytes (25).

\section{DPP Family Members in Cell-Mediated Immunity}

Dipeptidyl peptidase IV was originally described as a surface marker for T-lymphocytes, in which case it is better known as CD26, and later more specifically for a subset of CD4-positive memory cells, $\mathrm{CD}^{+}{ }^{+} \mathrm{CD} 45 \mathrm{RO}^{+} \mathrm{CD}^{+} 9^{+}$cells, which respond maximally to recall antigen tetanus toxoid and induce B-cell IgG synthesis $(165,166)$. Indeed, CD26 surface expression is augmented along with the antigen sensitivity of a particular $\mathrm{CD} 4^{+}$ T-cell clone (167). CD26 ${ }^{\text {high }} \mathrm{CD}^{+}$T-cells belong to the early effector memory T-cell subset (168). CD26 is also a marker for T-cell activation $(165,169-171)$. CD26 expression on CD4 ${ }^{+} \mathrm{T}$ cells correlates with $\mathrm{T}_{\mathrm{H}} 1$ responses. Stimuli that typically induce a $\mathrm{T}_{\mathrm{H}} 1$ phenotype tend to induce CD26 expression (172). Additionally, the $\mathrm{CD}^{+}{ }^{+} \mathrm{T}$ cells capable of transendothelial migration in vitro are characterized by a bright expression of CD26 (173, 174), but CD26 does not seem to be actually involved in T-cell adhesion to endothelial cells or fibroblasts (175). Recently, it was shown that up to $98 \%$ of all $\mathrm{T}_{\mathrm{H}} 17$ cells show very high $\mathrm{CD} 26$ expression, with mean fluorescent intensity on these cells almost twice as high as on $\mathrm{T}_{\mathrm{H}} 1$ or $\mathrm{T}_{\mathrm{H}} 2$ cells. Therefore, the authors of this study suggest $\mathrm{CD} 26$ as a marker for $\mathrm{T}_{\mathrm{H}} 17$ cells (176). Conversely, CD26 has been proposed as a negative marker for the selection $\mathrm{T}_{\text {reg }}$ cells due to its very low-surface expression on these cells (176-178).

CD26 is also a costimulatory molecule for T-cell activation. Crosslinking of CD26, along with CD3, stimulates T-cell activation and proliferation $(168,179,180)$. CD26 can also directly activate T-cells in an alternative activation pathway, but this requires the presence of the TCR/CD3 complex (181-183). During costimulation, CD26 is mannose- 6 phosphorylated and internalized, the latter of which is mediated in part by its interaction with M6P/IGFIIR (184). It then localizes to lipid rafts where it might interact with CD45, required for TCR signaling, facilitating colocalization of this molecule with TCR signaling molecules (185, 186). A number of candidate binding partners for costimulation have been proposed. ADA and CD26 are known binding partners (187). Even though ADA binding to CD26 does not seem to be essential for immune functions in humans (188), the nanomolar affinity of this interaction probably reflects its importance (189). Indeed, association with free ADA or ADA presented by ADA-anchoring proteins on dendritic cells seems to costimulate T-cells through CD26 binding $(190,191)$. On the other hand, it has been shown that soluble DPPIV enhances T-cell proliferation independent of its enzyme activity or ADA-binding capability (192). Interestingly, the ADA-CD26 interaction can be inhibited by HIV-1 external envelope protein gp120 and this requires interaction of gp120 with CXCR4 (189). In fact, evidence suggests a physical association between CXCR4 and CD26 


\section{- Low expression (82, 135-138)}

- Upregulation in obesity (123)

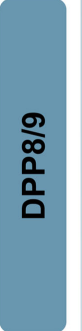

- Present in macrophage-rich regions in plaque (82)

- DPP9 is upregulated upon differentiation (82)

- DPP9 inhibition attenuates M1 macrophage activation (82)

- Expression proven in monocytes and macrophages $(25,136,147,148)$

Expressed in rat pulmonary and peritoneal macrophages (134,

151, 152)

- Secreted by THP-1 cells (153)

- Expressed by TAMs in human breast cancer (145)

- High activity in human bloodderived and alveolar macrophages $(138,149)$

- Increased wound-infiltrating macrophages in PRCP genetrap mice (150)

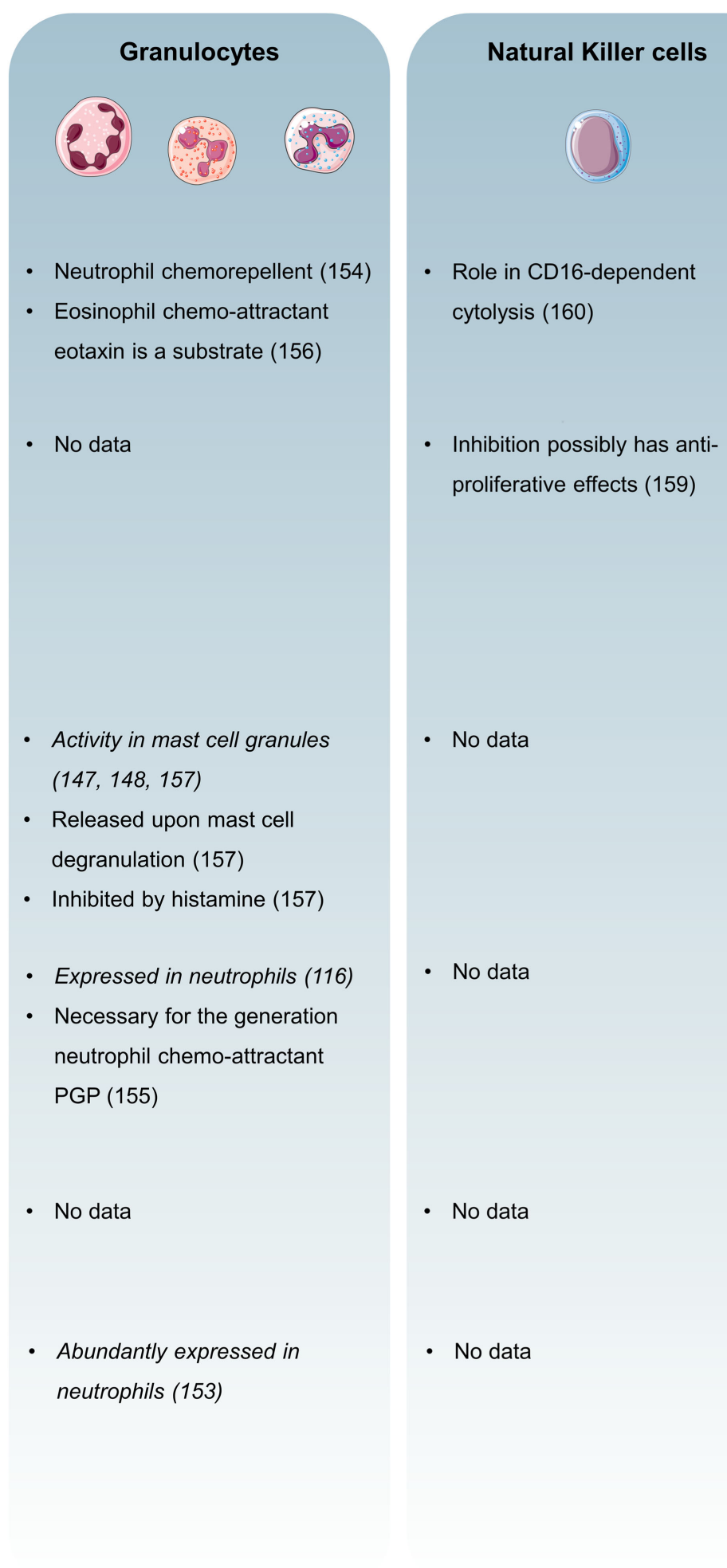

Role in CD16-dependent cytolysis (160)

- Inhibition possibly has antiproliferative effects (159)

- No data

- No data

- No data

- No data

FIGURE 3 | Overview of the expression and function of individual DPP family members in the innate immune system. Expression-based evidence is in italic.

on peripheral blood lymphocytes (193). Fibronectin is another known binding partner of CD26 involved in T-cell costimulation (194-196). Finally, CD26 interacts with caveolin-1 on monocytes.
This interaction causes an upregulation of CD86 on these cells, which potentiates antigen-specific T-cell activation (197). Most studies seem to find no need for DPPIV's enzymatic activity for 
succesful costimulation, as evidenced through the use of inhibitors and catalytically impaired DPPIV mutants (198-201).

Dipeptidyl peptidase 8 and 9 are present in baboon spleen interfollicular T-lymphocytes and Jurkat T cells (164). They are upregulated in the latter after PWM and LPS, but not PHA, stimulation $(163,202,203)$. Activation of PWM-stimulated T-cells is suppressed after DPPIV/8/9 inhibition. Moreover, DNA synthesis and T-cell proliferation are reduced, as well as production of IL-2, $10,-12$, and IFN- $\gamma$. This is due to an induction of TGF- $\beta$ secretion (159, 204-207). Inhibition also upregulates CTLA-4 and downregulates DPPIV expression $(206,208)$. These observations might be physiologically relevant as endogenous inhibitors of DPPs are known which have similar effects in cell-based experiments as the synthetic inhibitors $(209,210)$.

Dipeptidyl peptidase II activity is higher in T-lymphocytes than in B-lymphocytes (25) and absence of DPPII steers T-lymphocytes toward a $\mathrm{T}_{\mathrm{H}} 17$ phenotype. T-lymphocytes of DPPII KO mice hyperproliferate and secrete IL-17 after CD3 crosslinking or after in vivo priming and in vitro antigen-specific restimulation (211). PREP activity has also been shown in mouse T-lymphocytes (212). Its activity is significantly higher in immature, double-positive thymocytes compared to mature, single-positive thymocytes, or peripheral T-cells. T-cells stimulated with Con A followed by IL-2 show a time-dependent increase in PREP activity and pretreatment of cells with a PREP inhibitor renders them resistant to activation-induced cell death (212).

Figure 4 shows an overview of in vitro data on DPP involvement in primary human $\mathrm{T}$ cell activation.

\section{The DPP Family in Inflammatory Disease}

The DPP family has been reported to be dysregulated or even involved in a number of inflammatory disorders. Expression levels of a number of family members are modulated in rheumatoid

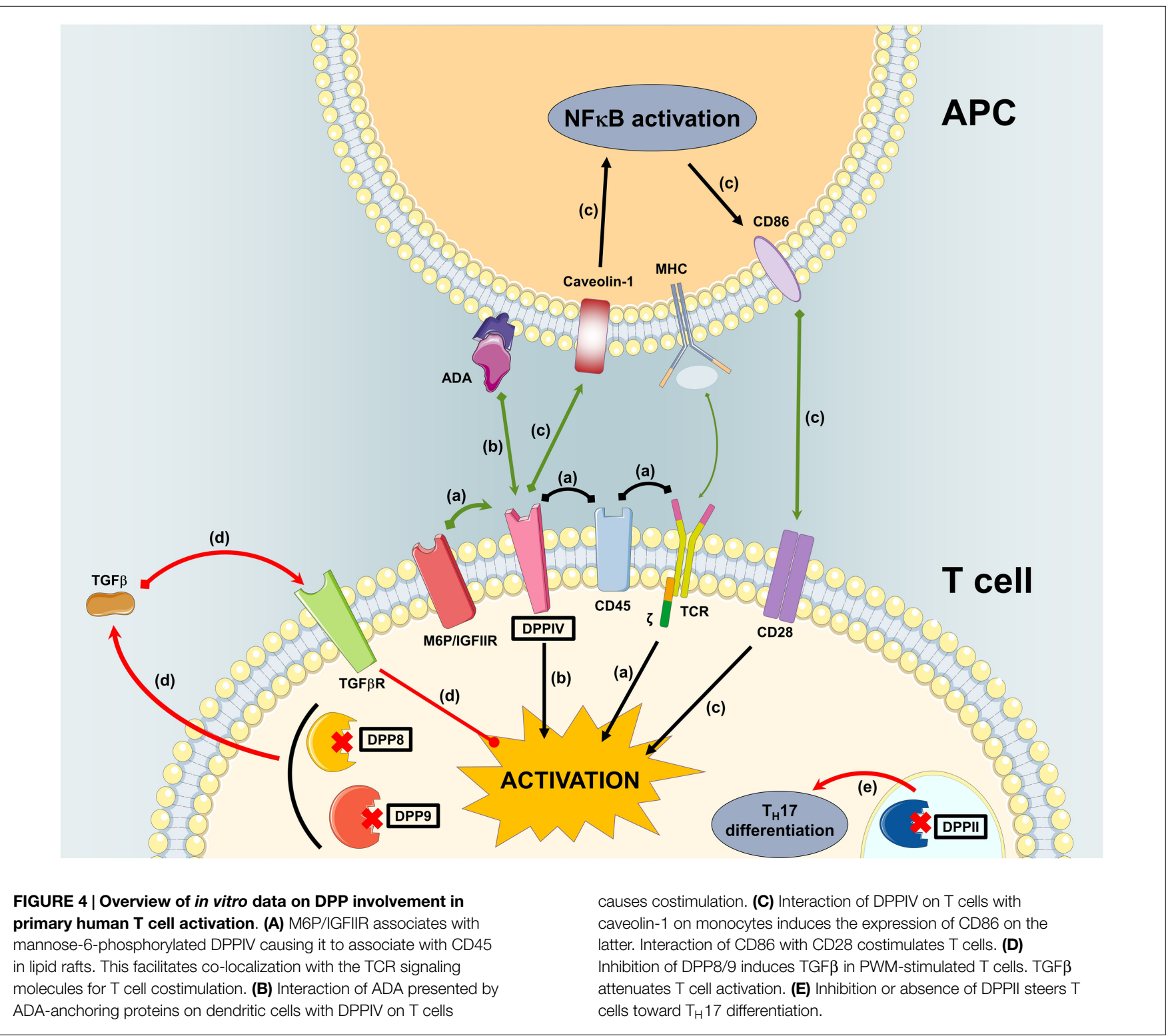


arthritis. Whereas the density of CD26 on peripheral T cells is increased in patients, it is low on synovial fluid T cells (213-215). DPPIV activity in plasma, serum, or synovial fluid of patients has also been found to be decreased, similar to results in several rat models of arthritis (216-222). Interestingly, rats resistant to induction of arthritis show higher plasma DPPIV levels (222). By contrast, DPPII and PREP activity are increased in serum or synovial fluid of arthritis patients (219-221). Likewise, FAP immunoreactivity is much higher in fibroblast-like synoviocytes of rheumatoid arthritis patients compared to osteoarthritis controls (223). DPPIV's involvement in rheumatoid arthritis has been studied, but remains unclear. On the one hand, inhibition can suppress development of arthritis in rats (224). Note, however, that effects mediated through other DPPs are hard to exclude as these inhibitors were developed before DPP8 and DPP9 were discovered. On the other hand, induced arthritis is more severe in DPPIV-deficient mice (216). This may be due to increased levels of circulating CXCL12 (216), a DPPIV substrate shown to be involved in rheumatoid arthritis. Several case reports in patients seem to suggest a link between the development of rheumatoid arthritis and the use of DPPIV inhibitors (225-227). PRCP has also been associated with rheumatoid arthritis as its activity was shown in synovial fluid isolated from arthritic joints (149).

Inflammatory bowel disease shows a distinct expression pattern of the DPP family. DPPIV serum or plasma activity seems to be lower in patients, whereas there is an increase of circulating $\mathrm{CD} 26^{+} \mathrm{CD} 25^{+}$cells with a higher CD26 surface expression $(228$, 229). FAP is heavily expressed by myofibroblasts in the submucosa strictures in Crohn's disease, and is upregulated after stimulation with TNF $\alpha$ or TGF $\beta$ (230). In a mouse model, colonic DPPII and DPP8 mRNA and DPPII activity are increased, while colonic DPP8/9 activity only increases significantly in mice that are also DPPIV knockouts (231). In mouse models, inhibition or abrogation of DPPIV seems to at least partially ameliorate symptoms, possibly by increasing circulating GLP-2, impairing neutrophil recruitment, and maintaining $\mathrm{T}_{\text {reg }}$ populations (231-236). Some of those beneficial effects may be mediated in part by the other DPPs, as additive effects were found for DPPIV KO and the DPP inhibitors $(231,234,237)$. A recent study suggests that the ameliorative effects of DPP inhibitors are most likely not mediated through GLP-2 protection (238).

The DPP family has also been studied in neuroinflammation. Ischemia-induced neuroinflammation in rats prompts a distinct expression and activity pattern of the DPPs. In the days following ischemia, the brain of these rats undergoes a complex reorganization of DPP expression with changes in mRNA, protein, and activity levels of DPPII, 4, 8, and 9 in cortical neurons, microglia, and macrophages (146). Similarly, PREP seems to be associated with astrocytes and microglia in lesioned inflamed brains of rats (239). DPPIV and PREP also may be involved in multiple sclerosis. $\mathrm{CD}^{2} 6^{+} \mathrm{T}$ cells were found to correlate with disease scores (240). Soluble DPPIV levels are elevated in cerebrospinal fluid of patients (241). Plasma PREP activity, on the other hand, is lower in patients with relapsing-remitting or primary progressive multiple sclerosis and in clinically isolated syndrome $(118,119)$. Interestingly, PREP inhibition seems to aggravate symptoms in a mouse model of multiple sclerosis (118).
In systemic lupus erythematosus, DPPs also seem to be dysregulated. In mouse models, DPPII and PREP activities are increased in plasma, spleen, kidney, and liver, whereas DPPIV activity is decreased $(221,242)$. Human patients also show elevated DPPII and reduced DPPIV activities in serum, along with reduced numbers of $\mathrm{CD}_{2} 6^{+} \mathrm{T}$ cells $(221,243)$. Interestingly, serum DPPIV levels are inversely correlated with disease score (243). FAP immunoreactivity is decreased in the synovium of lupus patients (244).

Finally, DPPIV has been studied in psoriasis, an immunemediated chronic inflammatory disorder with primary involvement of skin and joints. Its mRNA, protein levels and activity are higher in psoriatic skin samples $(245,246)$. By contrast, serum DPPIV levels and activity seem to be lower in patients (247, 248), accompanied by a reduction of peripheral $\mathrm{CD} 8^{+} \mathrm{CD} 26^{+}$ $\mathrm{T}$ cells $(249,250)$. Two case reports suggest a link between the use of DPPIV inhibitor sitagliptin and psoriasis. While one woman developed a psoriaform eruption 6 days after starting sitagliptin treatment (251), another patient's psoriatic lesions gradually diminished and were effectively gone 3 months after the start of sitagliptin treatment (252).

\section{The DPP Family in Atherosclerosis}

Dipeptidyl peptidase IV has recently received much attention for its potential as a therapeutic target for the treatment of atherosclerosis (Box 3) (253). This is not surprising considering the current use of DPPIV inhibitors in the treatment of T2D and the fact that T2D is associated with a higher risk for atherosclerosis $(28,254)$. In the $\mathrm{ApoE}^{-/-}$mouse model of atherosclerosis, DPPIV inhibition generally reduces plaque area and monocyte and macrophage plaque infiltration (255-257). A reduction in the number of plaque lesions or in smooth muscle cell content have also been observed $(255,256)$, as well as lower plaque MMP9 and higher plaque collagen levels, suggesting increased plaque stability (258). One study reported effects of DPPIV inhibition on atherosclerotic plaques of only diabetic ApoeE ${ }^{-1-}$ mice (141), but more recently, Terasaki et al. found similar effects in non-diabetic and diabetic ApoE ${ }^{-1-}$ mice (259). Likely, such differences can be explained by the fact that different DPPIV inhibitors were employed. Effects of DPPIV on atherogenesis similar to those observed in $\mathrm{ApoE}^{-1-}$ mice have been reproduced in $\operatorname{LDLR}^{-1-}$ mice $(142,260)$. In human atherosclerotic plaques,

\section{BOX 3 | Atherosclerosis.}

Atherosclerosis is the most common underlying cause of cardiovascular diseases and should be regarded as an inflammatory disease. It starts with dysfunction of the endothelium leading to the expression of leukocyte adhesion molecules, such as selectins and integrins. Locally produced proinflammatory cytokines attract the immune cells into the inner layer of the endothelium. However, not only leukocytes are found in the plaque but also low-density lipoprotein particles (LDL) and their oxidized counterparts (oxLDL). In the plaque, monocytes differentiate into macrophages, phagocytose the oxLDL and turn into so-called pro-atherogenic foam cells. This process leads to a self-sustaining, local inflammation leading to plaque growth, and migration of smooth muscle cells into the core. A plaque is defined as stable as long as it is contained by a thick fibrous cap. However, the latter is slowly degraded by the proteolytic enzymes from the leukocytes. This eventually leads to rupture and the formation of arterial thrombi $(264,265)$. 
DPPIV immunoreactivity could only be found on endothelium of neovessels (82). It was recently found that DPPIV activity may be a predictor for the onset of atherosclerosis in otherwise healthy Chinese individuals (261). Another prospective study investigated the influence of vildagliptin or sitagliptin treatment on intima-media thickness, a surrogate marker for atherosclerosis. This study found that treatment with vildagliptin or sitagliptin reduced intima-media thickness, suggesting that DPPIV inhibition might be beneficial in atherosclerosis in humans as well (262). Moreover, treatment naïve T2D patients treated with alogliptin

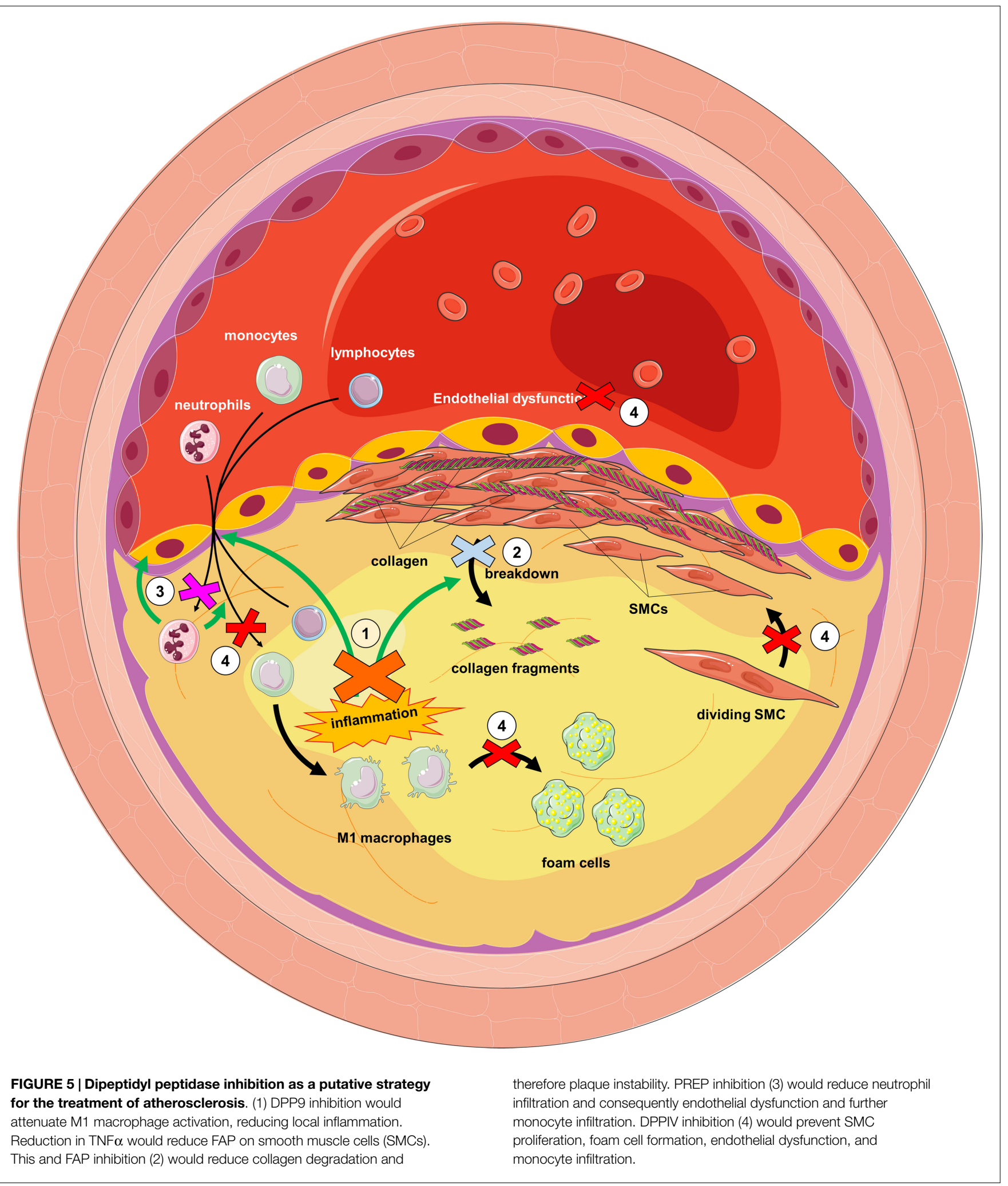


for 3 months saw a significant decrease in their circulating atherogenic lipids (263).

It has been suggested that DPPIV inhibitors' anti-atherogenic effects are mainly mediated through decreased monocyte infiltration, as DPPIV inhibitors suppress monocyte activation and chemotaxis in vitro $(142,258)$. DPPIV inhibition also reduces in vitro foam cell formation in exudate peritoneal macrophages from ApoE $\mathrm{E}^{-/-}$mice (255). Moreover, soluble DPPIV stimulates in vitro proliferation of smooth muscle cells and this can be reduced through the addition of a DPPIV inhibitor $(256,260)$. Finally, active circulating GLP-1 levels are augmented and this improves endothelial dysfunction $(259,266)$. Probably, DPPIV inhibition improves atherosclerosis through a combination of all these mechanisms. Indeed, incretin antagonists only partially attenuate the anti-atherogenic effects of DPPIV inhibition, suggesting that other mechanisms beyond incretin preservation are in play (259). Interestingly, monocyte-endothelial cell adhesion is abrogated by an anti-SDF- $1 \alpha$ antibody in vitro (267). LDL seems to induce SDF- $1 \alpha$ expression and leads to smooth muscle cell proliferation and inhibition of cell apoptosis $(267,268)$. SDF- $1 \alpha$ is a DPPIV substrate, which loses its biological activity after cleavage (216). As DPPIV inhibition seems to improve atherosclerosis, whereas intact SDF- $1 \alpha$ appears to be deletorious, it could be argued that SDF- $1 \alpha$ cleavage by DPPIV does not play a major role in atherosclerosis.

Dipeptidyl peptidase 8 and 9 have been found to be abundantly present in the macrophage-rich regions of human atherosclerotic plaques and considering DPP9's role in macrophage activation, it might potentially be involved in atherogenesis (82). FAP expression is enhanced in some, but not all types of human atheromata. It is found on smooth muscle cells, and its expression correlates with macrophage burden, probably due to the fact that TNF $\alpha$ upregulates FAP in smooth muscle cells in vitro. As it is mainly associated with collagen-poor regions and can digest type I collagen and gelatin in vitro, FAP probably contributes to plaque instability (269).

\section{References}

1. Broxmeyer HE, Hoggatt J, O'Leary H, Mantel C, Brahmananda C, Cooper $\mathrm{S}$, et al. Dipeptidylpeptidase 4 negatively regulates colony-stimulating factor activity and stress hematopoiesis. Nat Med (2012) 18:1786-96. doi:10.1038/ nm.2991.Dipeptidylpeptidase

2. Bezerra GA, Dobrovetsky E, Dong A, Seitova A, Crombett L, Shewchuk LM, et al. Structures of human DPP7 reveal the molecular basis of specific inhibition and the architectural diversity of proline-specific peptidases. PLoS One (2012) 7:e43019. doi:10.1371/journal.pone.0043019

3. Mentlein R, Struckhoff G. Purification of two dipeptidyl aminopeptidases II from rat brain and their action on proline-containing neuropeptides. J Neurochem (1989) 52:1284-93. doi:10.1111/j.1471-4159.1989.tb0 1877.x

4. Maes M-B, Scharpé S, De Meester I. Dipeptidyl peptidase II (DPPII), a review. Clin Chim Acta (2007) 380:31-49. doi:10.1016/j.cca.2007.01.024

5. Stöckel-Maschek A, Mrestani-Klaus C, Stiebitz B, Demuth H, Neubert K. Thioxo amino acid pyrrolidides and thiazolidides: new inhibitors of proline specific peptidases. Biochim Biophys Acta (2000) 1479:15-31. doi:10.1016/ S0167-4838(00)00054-6

6. Coutts SJ, Kelly TA, Snow RJ, Kennedy CA, Barton RW, Adams J, et al. Structure-activity relationships of boronic acid inhibitors of dipeptidyl
Interestingly, many of the studies reviewed above show the potential of targeting DPP family members for the treatment of atherosclerosis (see Figure 5). FAP inhibition might reduce plaque instability by decreasing collagen breakdown; DPP9 inhibition is likely to attenuate M1 macrophage activation, reducing the local inflammatory cascade; DPPIV inhibition may decrease monocyte infiltration, foam cell formation, improve endothelial dysfunction, and reduce smooth muscle cell proliferation; and finally, PREP inhibition might reduce neutrophil infiltration, preventing endothelial dysfunction, and monocyte infiltration. All of this shows the possibilities of repositioning DPPIV inhibitors, currently being used to treat type 2 diabetes, as well as the potential of targeting other members of the DPP family.

\section{Conclusion}

Caution should be taken when interpreting results from literature data based on DPP inhibitors, especially from older studies. It is now known that, under the experimental conditions used, many of these inhibitors are not specific for one particular family member. The reported findings, however, remain interesting. This review has shown extensive involvement of members of the DPP family in the immune system. It is clear that these enzymes hold great potential as targets for the treatment of certain inflammatory disorders. Particularly, the possibility of targeting DPP family members for the prevention and treatment of atherosclerosis warrants further investigation.

\section{Acknowledgments}

This work was supported by the University of Antwerp (GOA2009-2012) and the Flanders Research Foundation (FWO; Grant G0141.12). YW and KK are research fellows of the Flanders Research Foundation. Images were created based on Servier Medical Art licensed under Creative Commons Attribution 3.0 Unported License.

peptidase IV. 1. Variation of the P2 position of Xaa-boroPro dipeptides. J Med Chem (1996) 39:2087-94. doi:10.1021/jm950732f

7. Belyaev A, Zhang X, Augustyns K, Lambeir AM, De Meester I, Vedernikova I, et al. Structure-activity relationship of diaryl phosphonate esters as potent irreversible dipeptidyl peptidase IV inhibitors. J Med Chem (1999) 42:1041-52. doi:10.1021/jm981033g

8. Senten K, Daniëls L, Van der Veken P, De Meester I, Lambeir A-M, Scharpé $\mathrm{S}$, et al. Rapid parallel synthesis of dipeptide diphenyl phosphonate esters as inhibitors of dipeptidyl peptidases. J Comb Chem (2003) 5:336-44. doi:10. 1021/cc020096o

9. Van der Veken P, Senten K, Kertèsz I, De Meester I, Lambeir A-M, Maes M$\mathrm{B}$, et al. Fluoro-olefins as peptidomimetic inhibitors of dipeptidyl peptidases. J Med Chem (2005) 48:1768-80. doi:10.1021/jm0495982

10. Myöhänen TT, Tenorio-Laranga J, Jokinen B, Vázquez-Sánchez R, MorenoBaylach MJ, García-Horsman JA, et al. Prolyl oligopeptidase induces angiogenesis both in vitro and in vivo in a novel regulatory manner. Br J Pharmacol (2011) 163:1666-78. doi:10.1111/j.1476-5381.2010.01146.x

11. Myöhänen TT, Hannula MJ, Van Elzen R, Gerard M, Van Der Veken P, GarcíaHorsman JA, et al. A prolyl oligopeptidase inhibitor, KYP-2047, reduces $\alpha$-synuclein protein levels and aggregates in cellular and animal models of Parkinson's disease. Br J Pharmacol (2012) 166:1097-113. doi:10.1111/j. 1476-5381.2012.01846.x 
12. Jalkanen AJ, Piepponen TP, Hakkarainen JJ, De Meester I, Lambeir A-M, Forsberg MM. The effect of prolyl oligopeptidase inhibition on extracellular acetylcholine and dopamine levels in the rat striatum. Neurochem Int (2012) 60:301-9. doi:10.1016/j.neuint.2011.12.010

13. Ansorge S, Bank U, Heimburg A, Helmuth M, Koch G, Tadje J, et al. Recent insights into the role of dipeptidyl aminopeptidase IV (DPIV) and aminopeptidase N (APN) families in immune functions. Clin Chem Lab Med (2009) 47:253-61. doi:10.1515/CCLM.2009.063

14. Yazbeck R, Howarth GS, Abbott CA. Dipeptidyl peptidase inhibitors, an emerging drug class for inflammatory disease? Trends Pharmacol Sci (2009) 30:600-7. doi:10.1016/j.tips.2009.08.003

15. Ohnuma K, Dang NH, Morimoto C. Revisiting an old acquaintance: CD26 and its molecular mechanisms in T cell function. Trends Immunol (2008) 29:295-301. doi:10.1016/j.it.2008.02.010

16. Feng J, Zhang Z, Wallace MB, Stafford JA, Kaldor SW, Kassel DB, et al. Discovery of alogliptin: a potent, selective, bioavailable, and efficacious inhibitor of dipeptidyl peptidase IV. J Med Chem (2007) 50:2297-300. doi:10.1021/ jm0703439

17. Thomas L, Eckhardt M, Langkopf E, Tadayyon M, Himmelsbach F, Mark M. (R)-8-(3-amino-piperidin-1-yl)-7-but-2-ynyl-3-methyl-1-(4-methylquinazolin-2-ylmethyl)-3,7-dihydro-purine-2,6-dione (BI 1356), a novel xanthine-based dipeptidyl peptidase 4 inhibitor, has a superior potency and longer duration of action compared with oth. J Pharmacol Exp Ther (2008) 325:175-82. doi:10.1124/jpet.107.135723

18. Augeri DJ, Robl JA, Betebenner DA, Magnin DR, Khanna A, Robertson JG, et al. Discovery and preclinical profile of saxagliptin (BMS-477118): a highly potent, long-acting, orally active dipeptidyl peptidase IV inhibitor for the treatment of type 2 diabetes. J Med Chem (2005) 48:5025-37. doi:10.1021/ jm050261p

19. Kim D, Wang L, Beconi M, Eiermann GJ, Fisher $\mathrm{MH}, \mathrm{He} \mathrm{H}$, et al. (2R)-4-oxo-4-[3-(trifluoromethyl)-5,6-dihydro[1,2,4]triazolo[4,3-a]pyrazin$7(8 \mathrm{H})$-yl]-1-(2,4,5-trifluorophenyl)butan-2-amine: a potent, orally active dipeptidyl peptidase IV inhibitor for the treatment of type 2 diabetes. J Med Chem (2005) 48:141-51. doi:10.1021/jm0493156

20. Villhauer EB, Brinkman JA, Naderi GB, Burkey BF, Dunning BE, Prasad K, et al. 1-[[(3-hydroxy-1-adamantyl)amino]acetyl]-2-cyano-(S)-pyrrolidine: a potent, selective, and orally bioavailable dipeptidyl peptidase IV inhibitor with antihyperglycemic properties. J Med Chem (2003) 46:2774-89. doi:10.1021/ jm0300911

21. Wu J-J, Tang H-K, Yeh T-K, Chen C-M, Shy H-S, Chu Y-R, et al. Biochemistry, pharmacokinetics, and toxicology of a potent and selective DPP8/9 inhibitor. Biochem Pharmacol (2009) 78:203-10. doi:10.1016/j.bcp.2009.03.032

22. Ryabtsova O, Jansen K, Van Goethem S, Joossens J, Cheng JD, Lambeir A-M, et al. Acylated Gly-(2-cyano)pyrrolidines as inhibitors of fibroblast activation protein (FAP) and the issue of FAP/prolyl oligopeptidase (PREP)-selectivity. Bioorg Med Chem Lett (2012) 22:3412-7. doi:10.1016/j.bmcl.2012.03.107

23. Jansen K, Heirbaut L, Cheng JD, Joossens J, Ryabtsova O, Cos P, et al. Selective inhibitors of fibroblast activation protein (FAP) with a (4-quinolinoyl)-glycyl2-cyanopyrrolidine scaffold. ACS Med Chem Lett (2013) 4:491-6. doi:10.1021/ ml300410d

24. Van Goethem S, Matheeussen V, Joossens J, Lambeir A-M, Chen X, De Meester I, et al. Structure-activity relationship studies on isoindoline inhibitors of dipeptidyl peptidases 8 and 9 (DPP8, DPP9): is DPP8-selectivity an attainable goal? J Med Chem (2011) 54:5737-46. doi:10.1021/jm200383j

25. Maes M-B, Martinet W, Schrijvers DM, Van der Veken P, De Meyer GR, Augustyns K, et al. Dipeptidyl peptidase II and leukocyte cell death. Biochem Pharmacol (2006) 72:70-9. doi:10.1016/j.bcp.2006.04.009

26. Wilk S, Orlowski M. Inhibition of rabbit brain prolyl endopeptidase by $\mathrm{n}$ benzyloxycarbonyl-prolyl-prolinal, a transition state aldehyde inhibitor. J Neurochem (1983) 41:69-75. doi:10.1111/j.1471-4159.1983.tb11815.x

27. Rabey FM, Gadepalli RS, Diano S, Cheng Q, Tabrizian T, Gailani D, et al. Influence of a novel inhibitor (UM8190) of prolylcarboxypeptidase (PRCP) on appetite and thrombosis. Curr Med Chem (2012) 19:4194-206. doi:10.2174/ 092986712802430036

28. Deacon CF. Dipeptidyl peptidase- 4 inhibitors in the treatment of type 2 diabetes: a comparative review. Diabetes Obes Metab (2011) 13:7-18. doi:10. 1111/j.1463-1326.2010.01306.x

29. Kieffer TJ, McIntosh CH, Pederson RA. Degradation of glucose-dependent insulinotropic polypeptide and truncated glucagon-like peptide 1 in vitro and in vivo by dipeptidyl peptidase IV. Endocrinology (1995) 136:3585-96. doi:10.1210/endo.136.8.7628397

30. Drucker DJ, Shi Q, Crivici A, Sumner-Smith M, Tavares W, Hill M, et al. Regulation of the biological activity of glucagon-like peptide 2 in vivo by dipeptidyl peptidase IV. Nat Biotechnol (1997) 15:673-7. doi:10.1038/nbt0797-673

31. Ahmad S, Wang L, Ward PE. Dipeptidyl(amino)peptidase IV and aminopeptidase $\mathrm{M}$ metabolize circulating substance $\mathrm{P}$ in vivo. J Pharmacol Exp Ther (1992) 260:1257-61.

32. Frerker N, Wagner L, Wolf R, Heiser U, Hoffmann T, Rahfeld J-U, et al. Neuropeptide Y (NPY) cleaving enzymes: structural and functional homologues of dipeptidyl peptidase 4. Peptides (2007) 28:257-68. doi:10.1016/j.peptides. 2006.09.027

33. Proost P, Struyf S, Schols D, Durinx C, Wuyts A, Lenaerts JP, et al. Processing by CD26/dipeptidyl-peptidase IV reduces the chemotactic and anti-HIV1 activity of stromal-cell-derived factor-1alpha. FEBS Lett (1998) 432:73-6. doi:10.1016/S0014-5793(98)00830-8

34. Casrouge A, Decalf J, Ahloulay M, Lababidi C, Mansour H, Vallet-pichard A, et al. Evidence for an antagonist form of the chemokine CXCL10 in patients chronically infected with HCV. J Clin Invest (2011) 121(1):308-17. doi:10. 1172/JCI40594DS1

35. Rainczuk A, Rao JR, Gathercole JL, Fairweather NJ, Chu S, Masadah R, et al. Evidence for the antagonistic form of CXC-motif chemokine CXCL10 in serous epithelial ovarian tumours. Int J Cancer (2014) 134:530-41. doi:10. 1002/ijc. 28393

36. Barreira da Silva R, Laird ME, Yatim N, Fiette L, Ingersoll MA, Albert ML. Dipeptidylpeptidase 4 inhibition enhances lymphocyte trafficking, improving both naturally occurring tumor immunity and immunotherapy. Nat Immunol (2015). doi:10.1038/ni.3201

37. Marchetti C, Di Carlo A, Facchiano F, Senatore C, De Cristofaro R, Luzi A, et al. High mobility group box 1 is a novel substrate of dipeptidyl peptidase-IV. Diabetologia (2012) 55:236-44. doi:10.1007/s00125-011-2213-6

38. Oravecz T, Pall M, Roderiquez G, Gorrell MD, Ditto M, Nguyen NY, et al Regulation of the receptor specificity and function of the chemokine RANTES (regulated on activation, normal T cell expressed and secreted) by dipeptidyl peptidase IV (CD26)-mediated cleavage. J Exp Med (1997) 186:1865-72. doi:10.1084/jem.186.11.1865

39. Stulc T, Sedo A. Inhibition of multifunctional dipeptidyl peptidase-IV: is there a risk of oncological and immunological adverse effects? Diabetes Res Clin Pract (2010) 88:125-31. doi:10.1016/j.diabres.2010.02.017

40. Havre PA, Abe M, Urasaki Y, Ohnuma K, Morimoto C, Dang NH. The role of CD26/dipeptidyl peptidase IV in cancer. Front Biosci (2008) 13:1634-45. doi:10.2741/2787

41. Tinoco AD, Tagore DM, Saghatelian A. Expanding the dipeptidyl peptidase 4regulated peptidome via an optimized peptidomics platform. J Am Chem Soc (2010) 132:3819-30. doi:10.1021/ja909524e

42. Baggio LL, Drucker DJ. Biology of incretins: GLP-1 and GIP. Gastroenterology (2007) 132:2131-57. doi:10.1053/j.gastro.2007.03.054

43. Matheeussen V, Jungraithmayr W, De Meester I. Dipeptidyl peptidase 4 as a therapeutic target in ischemia/reperfusion injury. Pharmacol Ther (2012) 136:267-82. doi:10.1016/j.pharmthera.2012.07.012

44. Sonne DP, Engstrøm T, Treiman M. Protective effects of GLP-1 analogues exendin-4 and GLP-1(9-36) amide against ischemia-reperfusion injury in rat heart. Regul Pept (2008) 146:243-9. doi:10.1016/j.regpep.2007.10.001

45. Lønborg J, Vejlstrup N, Kelbæk H, Bøtker HE, Kim WY, Mathiasen AB, et al. Exenatide reduces reperfusion injury in patients with ST-segment elevation myocardial infarction. Eur Heart J (2012) 33:1491-9. doi:10.1093/eurheartj/ ehr309

46. Drucker D, Nauck M. The incretin system: glucagon-like peptide-1 receptor agonists and dipeptidyl peptidase-4 inhibitors in type 2 diabetes. Lancet (2006) 368:1696-705. doi:10.1016/S0140-6736(06)69705-5

47. Kotačková L, Balážiová E, Šedo A. Expression pattern of dipeptidyl peptidase IV activity and/or structure homologues in cancer. Folia Biol (2009) 84: 77-84.

48. Bušek P, Malík R, Šedo A. Dipeptidyl peptidase IV activity and/or structure homologues (DASH) and their substrates in cancer. Int J Biochem Cell Biol (2004) 36:408-21. doi:10.1016/S1357-2725(03)00262-0

49. Arrebola Y, Gomez H, Valiente P, de los A Chavez M, Pascual I. Dipeptidyl peptidase IV and its implication in cancer. Biotecnol Apl (2014) 31: 102-10. 
50. Busek P, Sedo A. Dipeptidyl peptidase-IV and related proteases in brain tumors. In: Lichtor T, editor. Evolution of the Molecular biology of Brain Tumors and the Therapeutic Implications. InTech (2013). p. 235-69. doi:10.5772/53888

51. Yu DM, Yao T-W, Chowdhury S, Nadvi NA, Osborne B, Church WB, et al. The dipeptidyl peptidase IV family in cancer and cell biology. FEBS J (2010) 277:1126-44. doi:10.1111/j.1742-4658.2009.07526.x

52. Raj VS, Mou H, Smits SL, Dekkers DH, Müller MA, Dijkman R, et al. Dipeptidyl peptidase 4 is a functional receptor for the emerging human coronavirusEMC. Nature (2013) 495:251-4. doi:10.1038/nature12005

53. Scirica BM, Braunwald E, Raz I, Cavender MA, Morrow DA, Jarolim P, et al. Heart failure, saxagliptin and diabetes mellitus: observations from the SAVOR - TIMI 53 randomized trial. Circulation (2014) 130:1579-88. doi:10. 1161/CIRCULATIONAHA.114.010389

54. Fadini GP, Avogaro A. Cardiovascular effects of DPP-4 inhibition: beyond GLP-1. Vascul Pharmacol (2011) 55:10-6. doi:10.1016/j.vph.2011.05.001

55. Theiss HD, Brenner C, Engelmann MG, Zaruba M-M, Huber B, Henschel V, et al. Safety and efficacy of SITAgliptin plus GRanulocyte-colony-stimulating factor in patients suffering from acute myocardial infarction (SITAGRAMItrial) - rationale, design and first interim analysis. Int J Cardiol (2010) 145:282-4. doi:10.1016/j.ijcard.2009.09.555

56. Theiss HD, Gross L, Vallaster M, David R, Brunner S, Brenner C, et al. Antidiabetic gliptins in combination with G-CSF enhances myocardial function and survival after acute myocardial infarction. Int J Cardiol (2013) 168:3359-69. doi:10.1016/j.ijcard.2013.04.121

57. Collins PJ, McMahon G, O’Brien P, O’Connor B. Purification, identification and characterisation of seprase from bovine serum. Int J Biochem Cell Biol (2004) 36:2320-33. doi:10.1016/j.biocel.2004.05.006

58. Lee KN, Jackson KW, Christiansen VJ, Lee CS, Chun J-G, McKee PA. Antiplasmin-cleaving enzyme is a soluble form of fibroblast activation protein. Blood (2006) 107:1397-404. doi:10.1182/blood-2005-08-3452

59. Keane FM, Nadvi NA, Yao T-W, Gorrell MD. Neuropeptide Y, B-type natriuretic peptide, substance $\mathrm{P}$ and peptide $\mathrm{YY}$ are novel substrates of fibroblast activation protein- $\alpha$. FEBS $J$ (2011) 278:1316-32. doi:10.1111/j.1742-4658. 2011.08051.x

60. O'Brien P, O'Connor BF. Seprase: an overview of an important matrix serine protease. Biochim Biophys Acta (2008) 1784:1130-45. doi:10.1016/j.bbapap. 2008.01.006

61. Keane FM, Yao T-W, Seelk S, Gall MG, Chowdhury S, Poplawski SE, et al. Quantitation of fibroblast activation protein (FAP)-specific protease activity in mouse, baboon and human fluids and organs. FEBS Open Bio (2013) 4:43-54. doi:10.1016/j.fob.2013.12.001

62. Sulda ML, Abbott CA, Hildebrandt M. DPIV/CD26 and FAP in cancer: a tale of contradictions. Adv Exp Med Biol (2006) 575:197-206. doi:10.1007/ 0-387-32824-6_21

63. Narra K, Mullins SR, Lee H-O, Strzemkowski-Brun B, Magalong K, Christiansen VJ, et al. Phase II trial of single agent Val-boroPro (talabostat) inhibiting fibroblast activation protein in patients with metastatic colorectal cancer. Cancer Biol Ther (2007) 6:1691-9. doi:10.4161/cbt.6.11.4874

64. Eager RM, Cunningham CC, Senzer N, Richards DA, Raju RN, Jones B, et al. Phase II trial of talabostat and docetaxel in advanced non-small cell lung cancer. Clin Oncol (R Coll Radiol) (2009) 21:464-72. doi:10.1016/j.clon.2009. 04.007

65. Eager RM, Cunningham CC, Senzer NN, Stephenson J, Anthony SP, O'Day SJ, et al. Phase II assessment of talabostat and cisplatin in second-line stage IV melanoma. BMC Cancer (2009) 9:263. doi:10.1186/1471-2407-9-263

66. Bjelke JR, Christensen J, Nielsen PF, Branner S, Kanstrup AB, Wagtmann N, et al. Dipeptidyl peptidases 8 and 9: specificity and molecular characterization compared with dipeptidyl peptidase IV. Biochem J (2006) 396:391-9. doi:10. 1042/BJ20060079

67. Ajami K, Abbott CA, McCaughan GW, Gorrell MD. Dipeptidyl peptidase 9 has two forms, a broad tissue distribution, cytoplasmic localization and DPIVlike peptidase activity. Biochim Biophys Acta (2004) 1679:18-28. doi:10.1016/ j.bbaexp.2004.03.010

68. Qi SY, Riviere PJ, Trojnar J, Junien J-L, Akinsanya KO. Cloning and characterization of dipeptidyl peptidase 10, a new member of an emerging subgroup of serine proteases. Biochem J (2003) 373:179-89. doi:10.1042/BJ20021914

69. Justa-Schuch D, Möller U, Geiss-Friedlander R. The amino terminus extension in the long dipeptidyl peptidase 9 isoform contains a nuclear localization signal targeting the active peptidase to the nucleus. Cell Mol Life Sci (2014) 71(18):3611-26. doi:10.1007/s00018-014-1591-6

70. Ajami K, Pitman MR, Wilson CH, Park J, Menz RI, Starr AE, et al. Stromal cell-derived factors 1alpha and 1beta, inflammatory protein-10 and interferoninducible $\mathrm{T}$ cell chemo-attractant are novel substrates of dipeptidyl peptidase 8. FEBS Lett (2008) 582:819-25. doi:10.1016/j.febslet.2008.02.005

71. Lu C, Tilan JU, Everhart L, Czarnecka M, Soldin SJ, Mendu DR, et al. Dipeptidyl peptidases as survival factors in Ewing sarcoma family of tumors: implications for tumor biology and therapy. J Biol Chem (2011) 286:27494-505. doi:10.1074/jbc.M111.224089

72. Wilson CH, Indarto D, Doucet A, Pogson LD, Pitman MR, Menz RI, et al. Identifying natural substrates for dipeptidyl peptidase 8 (DP8) and DP9 using terminal amine isotopic labelling of substrates, TAILS, reveals in vivo roles in cellular homeostasis and energy metabolism. J Biol Chem (2013) 288:13936-49. doi:10.1074/jbc.M112.445841

73. Geiss-Friedlander R, Parmentier N, Möller U, Urlaub H, Van den Eynde BJ, Melchior F. The cytoplasmic peptidase DPP9 is rate-limiting for degradation of proline-containing peptides. J Biol Chem (2009) 284:27211-9. doi:10.1074/ jbc.M109.041871

74. Gall MG, Chen Y, Vieira de Ribeiro AJ, Zhang H, Bailey CG, Spielman DS, et al. Targeted inactivation of dipeptidyl peptidase 9 enzymatic activity causes mouse neonate lethality. PLoS One (2013) 8:e78378. doi:10.1371/journal.pone. 0078378

75. Dubois V, Van Ginneken C, De Cock H, Lambeir A-M, Van der Veken P, Augustyns K, et al. Enzyme activity and immunohistochemical localization of dipeptidyl peptidase 8 and 9 in male reproductive tissues. $J$ Histochem Cytochem (2009) 57:531-41. doi:10.1369/jhc.2009.952739

76. Zhu H, Zhou Z-M, Lu L, Xu M, Wang H, Li J-M, et al. Expression of a novel dipeptidyl peptidase 8 (DPP8) transcript variant, DPP8-v3, in human testis. Asian J Androl (2005) 7:245-55. doi:10.1111/j.1745-7262.2005. 00054.x

77. Pilla E, Möller U, Sauer G, Mattiroli F, Melchior F, Geiss-Friedlander R. A novel SUMO1-specific interacting motif in dipeptidyl peptidase 9 (DPP9) that is important for enzymatic regulation. J Biol Chem (2012) 287:44320-9. doi:10.1074/jbc.M112.397224

78. Pilla E, Kilisch M, Lenz C, Urlaub H, Geiss-Friedlander R. The SUMO1-E67 interacting loop peptide is an allosteric inhibitor of the dipeptidyl peptidases 8 and 9. J Biol Chem (2013) 288:32787-96. doi:10.1074/jbc.M113.489179

79. Fingerlin TE, Murphy E, Zhang W, Peljto AL, Brown KK, Steele MP, et al. Genome-wide association study identifies multiple susceptibility loci for pulmonary fibrosis. Nat Genet (2013) 45:613-20. doi:10.1038/ng.2609

80. Yu DM, Wang XM, McCaughan GW, Gorrell MD. Extraenzymatic functions of the dipeptidyl peptidase IV-related proteins DP8 and DP9 in cell adhesion, migration and apoptosis. FEBS J (2006) 273:2447-60. doi:10.1111/j. 1742-4658.2006.05253.x

81. Yao TW, Kim WS, Yu DM, Sharbeen G, McCaughan GW, Choi KY, et al. A novel role of dipeptidyl peptidase 9 in epidermal growth factor signaling. $\mathrm{Mol}$ Cancer Res (2011) 9:948-59. doi:10.1158/1541-7786.MCR-10-0272

82. Matheeussen V, Waumans Y, Martinet W, Van Goethem S, Van der Veken P, Scharpé S, et al. Dipeptidyl peptidases in atherosclerosis: expression and role in macrophage differentiation, activation and apoptosis. Basic Res Cardiol (2013) 108:350-64. doi:10.1007/s00395-013-0350-4

83. Spagnuolo PA, Hurren R, Gronda M, MacLean N, Datti A, Basheer A, et al. Inhibition of intracellular dipeptidyl peptidases 8 and 9 enhances parthenolide's anti-leukemic activity. Leukemia (2013) 27:1236-44. doi:10.1038/leu. 2013.9

84. Maes M, Lambeir A, Gilany K, Senten K, Van der Veken P, Leiting B, et al. Kinetic investigation of human dipeptidyl peptidase II (DPPII)-mediated hydrolysis of dipeptide derivatives and its identification as quiescent cell proline dipeptidase (QPP)/dipeptidyl peptidase 7 (DPP7). Biochem J (2005) 324:315-24.

85. Kehoe K, Verkerk R, Sim Y, Waumans Y, Van der Veken P, Lambeir A-M, et al. Validation of a specific prolylcarboxypeptidase activity assay and its suitability for plasma and serum measurements. Anal Biochem (2013) 443:232-9. doi:10. 1016/j.ab.2013.09.002

86. O’Donoghue AJ, Eroy-Reveles AA, Knudsen GM, Ingram J, Zhou M, Statnekov JB, et al. Global identification of peptidase specificity by multiplex substrate profiling. Nat Methods (2012) 9:1095-100. doi:10.1038/nmeth.2182 
87. Shariat-Madar Z, Mahdi F, Schmaier AH. Recombinant prolylcarboxypeptidase activates plasma prekallikrein. Blood (2004) 103:4554-61. doi:10.1182/ blood-2003-07-2510

88. Odya CE, Marinkovic DV, Hammon KJ, Stewart TA, Erdös EG. Purification and properties of prolylcarboxypeptidase (angiotensinase C) from human kidney. J Biol Chem (1978) 253:5927-31.

89. Diano S. New aspects of melanocortin signaling: a role for PRCP in $\alpha$ MSH degradation. Front Neuroendocrinol (2011) 32:70-83. doi:10.1016/j. yfrne.2010.09.001

90. Xu S, Lind L, Zhao L, Lindahl B, Venge P. Plasma prolylcarboxypeptidase (angiotensinase C) is increased in obesity and diabetes mellitus and related to cardiovascular dysfunction. Clin Chem (2012) 58:1110-5. doi:10.1373/ clinchem.2011.179291

91. Kehoe K, Brouns R, Verkerk R, Engelborghs S, De Deyn PP, Hendriks D, et al. Prolyl carboxypeptidase activity decline correlates with severity and short-term outcome in acute ischemic stroke. Neurochem Res (2015) 40:81-8. doi:10.1007/s11064-014-1468-y

92. Chiravuri M, Schmitz T, Yardley K, Underwood R, Dayal Y, Huber BT. A novel apoptotic pathway in quiescent lymphocytes identified by inhibition of a postproline cleaving aminodipeptidase: a candidate target protease, quiescent cell proline dipeptidase. J Immunol (1999) 163:3092-9.

93. Mele DA, Bista P, Baez DV, Huber BT. Dipeptidyl peptidase 2 is an essential survival factor in the regulation of cell quiescence. Cell Cycle (2009) 8:2425-34. doi:10.4161/cc.8.15.9144

94. Danilov AV, Danilova OV, Brown JR, Rabinowitz A, Klein AK, Huber BT. Dipeptidyl peptidase 2 apoptosis assay determines the B-cell activation stage and predicts prognosis in chronic lymphocytic leukemia. Exp Hematol (2010) 38:1167-77. doi:10.1016/j.exphem.2010.08.008

95. Maes M, Lambeir A, Van Der Veken P, De Winter B, Augustyns K, Scharp S. In vivo effects of a potent, selective DPPII inhibitor: UAMC00039 is a possible tool for the elucidation of the physiological function of DPPII. Adv Exp Med Biol (2006) 575:73-85. doi:10.1007/0-387-32824-6_8

96. Schulz I, Zeitschel U, Rudolph T, Ruiz-Carrillo D, Rahfeld J-U, Gerhartz B, et al. Subcellular localization suggests novel functions for prolyl endopeptidase in protein secretion. J Neurochem (2005) 94:970-9. doi:10.1111/j.1471-4159. 2005.03237.x

97. Dresdner K, Barker LA, Orlowski M, Wilk S. Subcellular distribution of prolyl endopeptidase and cation-sensitive neutral endopeptidase in rabbit brain. J Neurochem (1982) 38:1151-4. doi:10.1111/j.1471-4159.1982.tb05362.x

98. Moreno-Baylach MJ, Felipo V, Männistö PT, García-Horsman JA. Expression and traffic of cellular prolyl oligopeptidase are regulated during cerebellar granule cell differentiation, maturation, and aging. Neuroscience (2008) 156:580-5. doi:10.1016/j.neuroscience.2008.06.072

99. Myöhänen TT, Venäläinen JI, García-Horsman JA, Piltonen M, Männistö PT. Distribution of prolyl oligopeptidase in the mouse whole-body sections and peripheral tissues. Histochem Cell Biol (2008) 130:993-1003. doi:10.1007/ s00418-008-0468-x

100. Walter R. Partial purification and characterization of post-proline cleaving enzyme: enzymatic inactivation of neurohypophyseal hormones by kidney preparations of various species. Biochim Biophys Acta (1976) 422:138-58. doi:10.1016/0005-2744(76)90015-2

101. Kato T, Nakano T, Kojima K, Nagatsu T, Sakakibara S. Changes in prolyl endopeptidase during maturation of rat brain and hydrolysis of substance $\mathrm{P}$ by the purified enzyme. J Neurochem (1980) 35:527-35. doi:10.1111/j.1471-4159. 1980.tb03687.x

102. Moriyama A, Nakanishi M, Sasaki M. Porcine muscle prolyl endopeptidase and its endogenous substrates. J Biochem (1988) 104:112-7.

103. Schönlein C, Heins J, Barth A. Purification and characterization of prolyl endopeptidase from pig brain. Biol Chem Hoppe Seyler (1990) 371:1159-64. doi:10.1515/bchm3.1990.371.2.1159

104. Kusuhara M, Hachisuka H, Nakano S, Sasai Y. Purification and characterization of prolyl endopeptidase from rat skin. J Dermatol Sci (1993) 6:138-45. doi:10.1016/0923-1811(93)90004-9

105. Bellemère G, Morain P, Vaudry H, Jégou S. Effect of S 17092, a novel prolyl endopeptidase inhibitor, on substance $\mathrm{P}$ and alpha-melanocyte-stimulating hormone breakdown in the rat brain. J Neurochem (2003) 84:919-29. doi:10. 1046/j.1471-4159.2003.01536.x

106. Browne P, O'Cuinn G. An evaluation of the role of a pyroglutamyl peptidase, a post-proline cleaving enzyme and a post-proline dipeptidyl amino peptidase, each purified from the soluble fraction of guinea-pig brain, in the degradation of thyroliberin in vitro. Eur J Biochem (1983) 137:75-87. doi:10.1111/j. 1432-1033.1983.tb07798.x

107. Männisto PT, Venäläinen J, Jalkanen A, García-Horsman JA. Prolyl oligopeptidase: a potential target for the treatment of cognitive disorders. Drug News Perspect (2007) 20:293-305. doi:10.1358/dnp.2007.20.5.1120216

108. García-Horsman JA, Männistö PT, Venäläinen JI. On the role of prolyl oligopeptidase in health and disease. Neuropeptides (2007) 41:1-24. doi:10. 1016/j.npep.2006.10.004

109. Camargo AC, Caldo H, Emson PC. Degradation of neurotensin by rabbit brain endo-oligopeptidase $\mathrm{A}$ and endo-oligopeptidase $\mathrm{B}$ (prolineendopeptidase). Biochem Biophys Res Commun (1983) 116:1151-9. doi:10. 1016/S0006-291X(83)80263-0

110. Cunningham DF, O'Connor B. Proline specific peptidases. Biochim Biophys Acta (1997) 1343:160-86. doi:10.1016/S0167-4838(97)00134-9

111. Greene LJ, Spadaro AC, Martins AR, Perussi De Jesus WD, Camargo AC. Brain endo-oligopeptidase B: a post-proline cleaving enzyme that inactivates angiotensin I and II. Hypertension (1982) 4:178-84. doi:10.1161/01.HYP.4.2. 178

112. Griffiths EC, McDermott JR, Smith AI. Inactivation of thyrotropin-releasing hormone (TRH) and (3Me-His) TRH by brain peptidases studied by highperformance liquid chromatography. Neurosci Lett (1982) 28:61-5. doi:10. 1016/0304-3940(82)90209-9

113. Mendez M, Cruz C, Joseph-Bravo P, Wilk S, Charli JL. Evaluation of the role of prolyl endopeptidase and pyroglutamyl peptidase I in the metabolism of LHRH and TRH in brain. Neuropeptides (1990) 17:55-62. doi:10.1016/ 0143-4179(90)90050-9

114. Mentlein R, von Kolszynski M, Sprang R, Lucius R. Proline-specific proteases in cultivated neuronal and glial cells. Brain Res (1990) 527:159-62. doi:10. 1016/0006-8993(90)91076-S

115. Toide K, Okamiya K, Iwamoto Y, Kato T. Effect of a novel prolyl endopeptidase inhibitor, JTP-4819, on prolyl endopeptidase activity and substance Pand arginine-vasopressin-like immunoreactivity in the brains of aged rats. J Neurochem (1995) 65:234-40. doi:10.1046/j.1471-4159.1995.65010234.x

116. O’Reilly PJ, Hardison MT, Jackson PL, Xu X, Snelgrove RJ, Gaggar A, et al. Neutrophils contain prolyl endopeptidase and generate the chemotactic peptide, PGP, from collagen. J Neuroimmunol (2009) 217:51-4. doi:10.1016/j. jneuroim.2009.09.020

117. Cavasin MA, Rhaleb N-E, Yang X-P, Carretero OA. Prolyl oligopeptidase is involved in release of the antifibrotic peptide Ac-SDKP. Hypertension (2004) 43:1140-5. doi:10.1161/01.HYP.0000126172.01673.84

118. Tenorio-Laranga J, Peltonen I, Keskitalo S, Duran-Torres G, Natarajan R, Männistö PT, et al. Alteration of prolyl oligopeptidase and activated $\alpha-2$ macroglobulin in multiple sclerosis subtypes and in the clinically isolated syndrome. Biochem Pharmacol (2013) 85:1783-94. doi:10.1016/j.bcp.2013.04. 018

119. Tenorio-Laranga J, Coret-Ferrer F, Casanova-Estruch B, Burgal M, GarcíaHorsman JA. Prolyl oligopeptidase is inhibited in relapsing-remitting multiple sclerosis. J Neuroinflammation (2010) 7:23. doi:10.1186/1742-2094-7-23

120. Yoshimoto T, Kado K, Matsubara F, Koriyama N, Kaneto H, Tsura D. Specific inhibitors for prolyl endopeptidase and their anti-amnesic effect. J Pharmacobiodyn (1987) 10:730-5. doi:10.1248/bpb1978.10.730

121. Toide K, Iwamoto Y, Fujiwara T, Abe H. JTP-4819: a novel prolyl endopeptidase inhibitor with potential as a cognitive enhancer. J Pharmacol Exp Ther (1995) 274:1370-8.

122. Shinoda M, Matsuo A, Toide K. Pharmacological studies of a novel prolyl endopeptidase inhibitor, JTP-4819, in rats with middle cerebral artery occlusion. Eur J Pharmacol (1996) 305:31-8. doi:10.1016/0014-2999(96) 00173-2

123. Shishido Y, Furushiro M, Tanabe S, Shibata S, Hashimoto S, Yokokura T. Effects of prolyl endopeptidase inhibitors and neuropeptides on delayed neuronal death in rats. Eur J Pharmacol (1999) 372:135-42. doi:10.1016/ S0014-2999(99)00185-5

124. Katsube N, Sunaga K, Aishita H, Chuang DM, Ishitani R. ONO-1603, a potential antidementia drug, delays age-induced apoptosis and suppresses overexpression of glyceraldehyde-3-phosphate dehydrogenase in cultured central nervous system neurons. J Pharmacol Exp Ther (1999) 288:6-13.

125. D’Agostino G, Kim JD, Liu Z-W, Jeong JK, Suyama S, Calignano A, et al. Prolyl endopeptidase-deficient mice have reduced synaptic spine density in the CA1 
region of the hippocampus, impaired LTP, and spatial learning and memory. Cereb Cortex (2013) 23:2007-14. doi:10.1093/cercor/bhs199

126. Di Daniel E, Glover CP, Grot E, Chan MK, Sanderson TH, White JH, et al. Prolyl oligopeptidase binds to GAP-43 and functions without its peptidase activity. Mol Cell Neurosci (2009) 41:373-82. doi:10.1016/j.mcn.2009. 03.003

127. Szeltner Z, Morawski M, Juhász T, Szamosi I, Liliom K, Csizmók V, et al. GAP43 shows partial co-localisation but no strong physical interaction with prolyl oligopeptidase. Biochim Biophys Acta (2010) 1804:2162-76. doi:10. 1016/j.bbapap.2010.09.010

128. Matsuda T, Sakaguchi M, Tanaka S, Yoshimoto T, Takaoka M. Prolyl oligopeptidase is a glyceraldehyde-3-phosphate dehydrogenase-binding protein that regulates genotoxic stress-induced cell death. Int J Biochem Cell Biol (2013) 45:850-7. doi:10.1016/j.biocel.2013.01.009

129. Lambeir A-M. Interaction of prolyl oligopeptidase with $\alpha$-synuclein. CNS Neurol Disord Drug Targets (2011) 10:349-54. doi:10.2174/ 187152711794653878

130. Hannula M, Myöhänen TT, Tenorio-Laranga J, Männistö PT, GarciaHorsman JA. Prolyl oligopeptidase colocalizes with $\alpha$-synuclein, $\beta$-amyloid, tau protein and astroglia in the post-mortem brain samples with Parkinson's and Alzheimer's diseases. Neuroscience (2013) 242:140-50. doi:10.1016/ j.neuroscience.2013.03.049

131. Brandt I, Gérard M, Sergeant K, Devreese B, Baekelandt V, Augustyns K, et al. Prolyl oligopeptidase stimulates the aggregation of alpha-synuclein. Peptides (2008) 29:1472-8. doi:10.1016/j.peptides.2008.05.005

132. Dimitrijević M, Stanojević S, Mitić K, Kustrimović N, Vujić V, Miletić T, et al. The anti-inflammatory effect of neuropeptide $\mathrm{Y}$ (NPY) in rats is dependent on dipeptidyl peptidase 4 (DP4) activity and age. Peptides (2008) 29:2179-87. doi:10.1016/j.peptides.2008.08.017

133. Wang Z, Grigo C, Steinbeck J, von Hörsten S, Amann K, Daniel C. Soluble DPP4 originates in part from bone marrow cells and not from the kidney. Peptides (2014) 57:109-17. doi:10.1016/j.peptides.2014.05.006

134. Olivo RD, Teixeira Cde F, Silveira PF. Representative aminopeptidases and prolyl endopeptidase from murine macrophages: comparative activity levels in resident and elicited cells. Biochem Pharmacol (2005) 69:1441-50. doi:10. 1016/j.bcp.2005.03.002

135. Zhong J, Rao X, Deiuliis J, Braunstein Z, Narula V, Hazey J, et al. A potential role for dendritic cell/macrophage-expressing DPP4 in obesity-induced visceral inflammation. Diabetes (2013) 62:149-57. doi:10.2337/db12-0230

136. Maes M-B, Dubois V, Brandt I, Lambeir A-M, Van der Veken P, Augustyns K, et al. Dipeptidyl peptidase 8/9-like activity in human leukocytes. J Leukoc Biol (2007) 81:1252-7. doi:10.1189/jlb.0906546

137. Bauvois B, Sancéau J, Wietzerbin J. Human U937 cell surface peptidase activities: characterization and degradative effect on tumor necrosis factor-alpha. Eur J Immunol (1992) 22:923-30. doi:10.1002/eji.1830220407

138. Jackman HL, Tan F, Schraufnagel D, Dragović T, Dezsö B, Becker RP, et al. Plasma membrane-bound and lysosomal peptidases in human alveolar macrophages. Am J Respir Cell Mol Biol (1995) 13:196-204. doi:10.1165/ ajrcmb.13.2.7626287

139. Laouar A, Wietzerbin J, Bauvois B. Divergent regulation of cell surface protease expression in HL-60 cells differentiated into macrophages with granulocyte macrophage colony stimulating factor or neutrophils with retinoic acid. Int Immunol (1993) 5:965-73. doi:10.1093/intimm/5.8.965

140. Ta NN, Li Y, Schuyler CA, Lopes-Virella MF, Huang Y. DPP-4 (CD26) inhibitor alogliptin inhibits TLR4-mediated ERK activation and ERKdependent MMP-1 expression by U937 histiocytes. Atherosclerosis (2010) 213:429-35. doi:10.1016/j.atherosclerosis.2010.08.064

141. Ta NN, Schuyler CA, Li Y, Lopes-Virella MF, Huang Y. DPP-4 (CD26) inhibitor alogliptin inhibits atherosclerosis in diabetic apolipoprotein Edeficient mice. J Cardiovasc Pharmacol (2011) 58:157-66. doi:10.1097/FJC. ob013e31821e5626

142. Shah Z, Kampfrath T, Deiuliis JA, Zhong J, Pineda C, Ying Z, et al. Longterm dipeptidyl-peptidase 4 inhibition reduces atherosclerosis and inflammation via effects on monocyte recruitment and chemotaxis. Circulation (2011) 124:2338-49. doi:10.1161/CIRCULATIONAHA.111.041418

143. Dai Y, Dai D, Wang X, Ding Z, Mehta JL. DPP-4 inhibitors repress NLRP3 inflammasome and interleukin-1beta via GLP-1 receptor in macrophages through protein kinase C pathway. Cardiovasc Drugs Ther (2014) 28(5):425-32. doi:10.1007/s10557-014-6539-4
144. Reinhold D, Bank U, Bühling F, Kähne T, Kunt D, Faust J, et al. Inhibitors of dipeptidyl peptidase IV (DP IV, CD26) specifically suppress proliferation and modulate cytokine production of strongly CD26 expressing U937 cells. Immunobiology (1994) 192:121-36. doi:10.1016/S0171-2985(11)80412-2

145. Tchou J, Zhang PJ, Bi Y, Satija C, Marjumdar R, Stephen TL, et al. Fibroblast activation protein expression by stromal cells and tumor-associated macrophages in human breast cancer. Hum Pathol (2013) 44:2549-57. doi:10. 1016/j.humpath.2013.06.016

146. Röhnert P, Schmidt W, Emmerlich P, Goihl A, Wrenger S, Bank U, et al. Dipeptidyl peptidase IV, aminopeptidase $\mathrm{N}$ and DPIV/APN-like proteases in cerebral ischemia. J Neuroinflammation (2012) 9:44-59. doi:10.1186/ 1742-2094-9-44

147. Sannes PL, McDonald JK, Allen RC, Spicer SS. Cytochemical localization and biochemical characterization of dipeptidyl aminopeptidase II in macrophages and mast cells. J Histochem Cytochem (1979) 27:1496-8. doi:10.1177/27.11. 512331

148. Randell SH, Sannes PL. Cytochemical localization and biochemical evaluation of a lysosomal serine protease in lung: dipeptidyl peptidase II in the normal rat. J Histochem Cytochem (1985) 33:677-86. doi:10.1177/33.7.3924993

149. Kumamoto K, Stewart TA, Johnson AR, Erdös EG. Prolylcarboxypeptidase (angiotensinase C) in human lung and cultured cells. J Clin Invest (1981) 67:210-5. doi:10.1172/JCI110015

150. Adams GN, Stavrou EX, Fang C, Merkulova A, Alaiti MA, Nakajima K, et al. Prolylcarboxypeptidase promotes angiogenesis and vascular repair. Blood (2013) 122:1522-31. doi:10.1182/blood-2012-10-460360.The

151. Green GD, Shaw E. A prolyl endopeptidase from murine macrophages, its assay and specific inactivation. Arch Biochem Biophys (1983) 225:331-7. doi:10.1016/0003-9861(83)90037-1

152. Lesser M, Chang JC, Orlowski J, Kilburn KH, Orlowski M. Cathepsin B and prolyl endopeptidase activity in rat peritoneal and alveolar macrophages. Stimulation of peritoneal macrophages by saline lavage. J Lab Clin Med (1983) 101:327-34.

153. Klegeris A, Li J, Bammler TK, Jin J, Zhu D, Kashima DT, et al. Prolyl endopeptidase is revealed following SILAC analysis to be a novel mediator of human microglial and THP-1 cell neurotoxicity. Glia (2008) 56:675-85. doi:10.1002/glia.20645

154. Herlihy SE, Pilling D, Maharjan AS, Gomer RH. Dipeptidyl peptidase IV is a human and murine neutrophil chemorepellent. J Immunol (2013) 190:6468-77. doi:10.4049/jimmunol.1202583

155. Gaggar A, Jackson PL, Noerager BD, Reilly PJ, McQuaid DB, Rowe SM, et al. A novel proteolytic cascade generates an extracellular matrix-derived chemoattractant in chronic neutrophilic inflammation. J Immunol (2008) 180:5662-9. doi:10.4049/jimmunol.180.8.5662

156. Forssmann U, Stoetzer C, Stephan M, Kruschinski C, Skripuletz T, Schade J, et al. Inhibition of CD26/dipeptidyl peptidase IV enhances CCL11/eotaxinmediated recruitment of eosinophils in vivo. J Immunol (2008) 181:1120-7. doi:10.4049/jimmunol.181.2.1120

157. Struckhoff G, Heymann E. Rat peritoneal mast cells release dipeptidyl peptidase II. Biochem J (1986) 236:215-9.

158. Bühling F, Kunz D, Reinhold D, Ulmer AJ, Ernst M, Flad HD, et al. Expression and functional role of dipeptidyl peptidase IV (CD26) on human natural killer cells. Nat Immun (1994) 13:270-9.

159. Lankas GR, Leiting B, Roy RS, Eiermann GJ, Beconi MG, Biftu T, et al. Dipeptidyl peptidase IV inhibition for the treatment of type 2 diabetes, potential importance of selectivity over dipeptidyl peptidases 8 and 9. Diabetes (2005) 54:2988-94. doi:10.2337/diabetes.54.10.2988

160. Madueño JA, Muñoz E, Blazquez V, Gonzalez R, Aparicio P, Peña J. The CD26 antigen is coupled to protein tyrosine phosphorylation and implicated in CD16-mediated lysis in natural killer cells. Scand J Immunol (1993) 37:425-9. doi:10.1111/j.1365-3083.1993.tb03313.x

161. Shingu K, Helfritz A, Zielinska-Skowronek M, Meyer-Olson D, Jacobs R, Schmidt RE, et al. CD26 expression determines lung metastasis in mutant F344 rats: involvement of NK cell function and soluble CD26. Cancer Immunol Immunother (2003) 52:546-54. doi:10.1007/s00262-003-0392-9

162. Bühling F, Junker U, Reinhold D, Neubert K, Jäger L, Ansorge S. Functional role of CD26 on human B lymphocytes. Immunol Lett (1995) 45:47-51. doi:10. 1016/0165-2478(94)00230-O

163. Chowdhury S, Chen Y, Yao T-W, Ajami K, Wang XM, Popov Y, et al. Regulation of dipeptidyl peptidase 8 and 9 expression in activated lymphocytes and 
injured liver. World J Gastroenterol (2013) 19:2883-93. doi:10.3748/wjg.v19. i1 19.2883

164. Yu DM, Ajami K, Gall MG, Park J, Lee CS, Evans KA, et al. The in vivo expression of dipeptidyl peptidases 8 and 9. J Histochem Cytochem (2009) 57:1025-40. doi:10.1369/jhc.2009.953760

165. Morimoto C, Torimoto Y, Levinson G, Rudd C, Schrieber M, Dang N, et al. $1 \mathrm{~F} 7$, a novel cell surface molecule, involved in helper function of CD4 cells. J Immunol (1989) 143:3430-9.

166. Schön E, Demuth HU, Barth A, Ansorge S. Dipeptidyl peptidase IV of human lymphocytes - evidence for specific hydrolysis of glycylproline p-nitroanilide in T-lymphocytes. Biochem J (1984) 223:255-8.

167. Falcioni F, Shah H, Vidović D, Morimoto C, Belunis C, Bolin D, et al. Influence of CD26 and integrins on the antigen sensitivity of human memory $\mathrm{T}$ cells. Hum Immunol (1996) 50:79-90. doi:10.1016/0198-8859(96)00121-8

168. Hatano R, Ohnuma K, Yamamoto J, Dang NH, Morimoto C. CD26-mediated co-stimulation in human $\mathrm{CD} 8(+) \mathrm{T}$ cells provokes effector function via proinflammatory cytokine production. Immunology (2013) 138:165-72. doi:10. $1111 / \mathrm{imm} .12028$

169. Schön E, Eichmann E, Grunow R, Jahn S, Kiessig ST, Volk HD, et al. Dipeptidyl peptidase IV in human T lymphocytes. An approach to the role of a membrane peptidase in the immune system. Biomed Biochim Acta (1986) 45: $1523-8$.

170. Schön E, Ansorge S. Dipeptidyl peptidase IV in the immune system. Cytofluorometric evidence for induction of the enzyme on activated T lymphocytes. Biol Chem Hoppe Seyler (1990) 371:699-705. doi:10.1515/bchm3.1990.371.2. 699

171. Fleischer B. A novel pathway of human T cell activation via a $103 \mathrm{kD}$ T cell activation antigen. J Immunol (1987) 138:1346-50.

172. Willheim M, Ebner C, Baier K, Kern W, Schrattbauer K, Thien R, et al. Cell surface characterization of $\mathrm{T}$ lymphocytes and allergen-specific $\mathrm{T}$ cell clones: correlation of CD26 expression with $\mathrm{T}(\mathrm{H} 1)$ subsets. J Allergy Clin Immunol (1997) 100:348-55. doi:10.1016/S0091-6749(97)70248-3

173. Brezinschek R, Lipsky PE, Galea P, Oppenheimer-Marks N. Phenotypic characterization of $\mathrm{CD} 4+\mathrm{T}$ cells that exhibit a transendothelial migratory capacity. J Immunol (1995) 154:3062-77.

174. Masuyama J, Yoshio T, Suzuki K, Kitagawa S, Iwamoto M, Kamimura T, et al. Characterization of the $4 \mathrm{C} 8$ antigen involved in transendothelial migration of CD26hi T cells after tight adhesion to human umbilical vein endothelial cell monolayers. J Exp Med (1999) 189:979-89. doi:10.1084/jem.189.6.979

175. Mattern T, Reich C, Schönbeck U, Ansorge S, Demuth HU, Loppnow H, et al. CD26 (dipeptidyl peptidase IV) on human T lymphocytes does not mediate adhesion of these cells to endothelial cells or fibroblasts. Immunobiology (1998) 198:465-75. doi:10.1016/S0171-2985(98)80053-3

176. Bengsch B, Seigel B, Flecken T, Wolanski J, Blum HE, Thimme R. Human Th17 cells express high levels of enzymatically active dipeptidylpeptidase IV (CD26). J Immunol (2012) 188:5438-47. doi:10.4049/jimmunol.1103801

177. Salgado FJ, Pérez-Díaz A, Villanueva NM, Lamas O, Arias P, Nogueira M. CD26: a negative selection marker for human Treg cells. Cytometry A (2012) 81:843-55. doi:10.1002/cyto.a.22117

178. Garcia Santana CA, Tung JW, Gulnik S. Human treg cells are characterized by low/negative CD6 expression. Cytometry A (2014) 85:901-8. doi:10.1002/cyto. a. 22513

179. Tanaka T, Camerini D, Seed B, Torimoto Y, Dang N, Kameoka J, et al. Cloning and functional expression of the T cell activation antigen CD26.J Immunol (1992) 149:481-6.

180. De Meester I, Kestens L, Vanham G, Vanhoof G, Vingerhoets J, Gigase P, et al. Costimulation of CD4+ and CD8+ T cells through CD26: the ADA-binding epitope is not essential for complete signaling. J Leukoc Biol (1995) 58:325-30.

181. Fleischer B, Sturm E, De Vries JE, Spits H. Triggering of cytotoxic T lymphocytes and NK cells via the Tp103 pathway is dependent on the expression of the T cell receptor/CD3 complex. J Immunol (1988) 141:1103-7.

182. Hegen M, Camerini D, Fleischer B. Function of dipeptidyl peptidase IV (CD26, Tp103) in transfected human T cells. Cell Immunol (1993) 146:249-60. doi:10.1006/cimm.1993.1024

183. Dang NH, Hafler DA, Schlossman SF, Breitmeyer JB. FcR-mediated crosslinking of Ta1 (CDw26) induces human T lymphocyte activation. Cell Immunol (1990) 125:42-57. doi:10.1016/0008-8749(90)90061-U

184. Ikushima $\mathrm{H}$, Munakata $\mathrm{Y}$, Ishii $\mathrm{T}$, Iwata $\mathrm{S}$, Terashima $\mathrm{M}$, Tanaka $\mathrm{H}$, et al. Internalization of $\mathrm{CD} 26$ by mannose 6-phosphate/insulin-like growth factor
II receptor contributes to T cell activation. Proc Natl Acad Sci U S A (2000) 97:8439-44. doi:10.1073/pnas.97.15.8439

185. Ishii T, Ohnuma K, Murakami A, Takasawa N, Kobayashi S, Dang NH, et al. CD26-mediated signaling for $\mathrm{T}$ cell activation occurs in lipid rafts through its association with CD45RO. Proc Natl Acad Sci U S A (2001) 98:12138-43. doi:10.1073/pnas.211439098

186. Torimoto Y, Dang N, Vivier E, Tanaka T, Schlossman S, Morimoto C. Coassociation of CD26 (dipeptidyl peptidase IV) with CD45 on the surface of human T lymphocytes. J Immunol (1991) 147:2514-7.

187. Kameoka J, Tanaka T, Nojima Y, Schlossman SF, Morimoto C. Direct association of adenosine deaminase with a $\mathrm{T}$ cell activation antigen, CD26. Science (1993) 261:466-9. doi:10.1126/science.8101391

188. Richard E, Arredondo-Vega FX, Santisteban I, Kelly SJ, Patel DD, Hershfield MS. The binding site of human adenosine deaminase for CD26/dipeptidyl peptidase IV: the Arg142Gln mutation impairs binding to $\mathrm{cd} 26$ but does not cause immune deficiency. J Exp Med (2000) 192:1223-36. doi:10.1084/jem. 192.9.1223

189. Blanco J, Valenzuela A, Herrera C, Lluís C, Hovanessian AG, Franco R. The HIV-1 gp120 inhibits the binding of adenosine deaminase to CD26 by a mechanism modulated by CD4 and CXCR4 expression. FEBS Lett (2000) 477:123-8. doi:10.1016/S0014-5793(00)01751-8

190. Pacheco R, Lejeune M, Climent N, Oliva H, Gatell JM, Gallart T, et al. CD26, adenosine deaminase, and adenosine receptors mediate costimulatory signals in the immunological synapse. Proc Natl Acad Sci U S A (2005) 102:9583-8. doi:10.1073/pnas.0501050102

191. Martín M, Huguet J, Centelles JJ, Franco R. Expression of ecto-adenosine deaminase and CD26 in human T cells triggered by the TCR-CD3 complex. Possible role of adenosine deaminase as costimulatory molecule. J Immunol (1995) 155:4630-43.

192. Yu DM, Slaitini L, Gysbers V, Riekhoff AG, Kähne T, Knott HM, et al. Soluble CD26/dipeptidyl peptidase IV enhances human lymphocyte proliferation in vitro independent of dipeptidyl peptidase enzyme activity and adenosine deaminase binding. Scand J Immunol (2011) 73:102-11. doi:10. $1111 / j .1365-3083.2010 .02488 . x$

193. Herrera C, Morimoto C, Blanco J, Mallol J, Arenzana F, Lluis C, et al. Comodulation of CXCR4 and CD26 in human lymphocytes. J Biol Chem (2001) 276:19532-9. doi:10.1074/jbc.M004586200

194. Cheng H-C, Abdel-Ghany M, Pauli BU. A novel consensus motif in fibronectin mediates dipeptidyl peptidase IV adhesion and metastasis. J Biol Chem (2003) 278:24600-7. doi:10.1074/jbc.M303424200

195. Davis LS, Oppenheimer-Marks N, Bednarczyk JL, Mcintyre BW, Lipsky PE. Fibronectin promotes proliferation of naive and memory $\mathrm{T}$ cells by signaling through both the VLA-4 and VLA-5 integrin molecules. J Immunol (1990) 145:785-93.

196. Noijma Y, Humphries MJ, Mould AP, Komoriya A, Yamada KM, Schlossman SF, et al. VLA-4 mediates CD3-dependent CD4+ T cell activation via the CS1 alternatively spliced domain of fibronectin. J Exp Med (1990) 172:1185-92. doi:10.1084/jem.172.4.1185

197. Ohnuma K, Yamochi T, Uchiyama M, Nishibashi K, Yoshikawa N, Shimizu $\mathrm{N}$, et al. CD26 up-regulates expression of CD86 on antigen-presenting cells by means of caveolin-1. Proc Natl Acad Sci U S A (2004) 101:14186-91. doi:10.1073/pnas.0405266101

198. Tanaka T, Kameoka J, Yaron A, Schlossman SF, Morimoto C. The costimulatory activity of the $\mathrm{CD} 26$ antigen requires dipeptidyl peptidase IV enzymatic activity. Proc Natl Acad Sci U S A (1993) 90:4586-90. doi:10.1073/pnas.90.10. 4586

199. Hegen M, Mittrücker HW, Hug R, Demuth HU, Neubert K, Barth A, et al. Enzymatic activity of CD26 (dipeptidylpeptidase IV) is not required for its signalling function in T cells. Immunobiology (1993) 189:483-93. doi:10.1016/ S0171-2985(11)80419-5

200. Hühn J, Ehrlich S, Fleischer B, von Bonin A. Molecular analysis of CD26mediated signal transduction in T cells. Immunol Lett (2000) 72:127-32. doi:10.1016/S0165-2478(00)00170-X

201. Steeg C, Hartwig U, Fleischer B. Unchanged signaling capacity of mutant CD26/dipeptidylpeptidase IV molecules devoid of enzymatic activity. Cell Immunol (1995) 164:311-5. doi:10.1006/cimm.1995.1175

202. Tang H-K, Tang H-Y, Hsu S-C, Chu Y-R, Chien C-H, Shu C-H, et al. Biochemical properties and expression profile of human prolyl dipeptidase DPP9. Arch Biochem Biophys (2009) 485:120-7. doi:10.1016/j.abb.2009.02.015 
203. Abbott CA, Yu DM, Woollatt E, Sutherland GR, McCaughan GW, Gorrell MD. Cloning, expression and chromosomal localization of a novel human dipeptidyl peptidase (DPP) IV homolog, DPP8. Eur J Biochem (2000) 267:6140-50. doi:10.1046/j.1432-1327.2000.01617.x

204. Reinhold D, Goihl A, Wrenger S, Reinhold A, Kühlmann UC, Faust J, et al. Role of dipeptidyl peptidase IV (DP IV)-like enzymes in T lymphocyte activation: investigations in DP IV/CD26-knockout mice. Clin Chem Lab Med (2009) 47:268-74. doi:10.1515/CCLM.2009.062

205. Reinhold D, Bank U, Buhling F, Lendeckel U, Faust J, Neubertt K. Inhibitors of dipeptidyl peptidase IV induce secretion of transforming growth factorß1 in PWM-stimulated PBMC and T cells. Immunology (1997) 91:354-60. doi:10.1046/j.1365-2567.1997.d01-2258.x

206. Arndt M, Lendeckel U, Spiess A, Faust J, Neubert K, Reinhold D, et al. Dipeptidyl peptidase IV (DP IV/CD26) mRNA expression in PWM-stimulated Tcells is suppressed by specific DP IV inhibition, an effect mediated by TGFbeta(1). Biochem Biophys Res Commun (2000) 274:410-4. doi:10.1006/bbrc. 2000.3144

207. Williams YN, Baba H, Hayashi S, Ikai H, Sugita T, Tanaka S, et al. Dipeptidyl peptidase IV on activated T cells as a target molecule for therapy of rheumatoid arthritis. Clin Exp Immunol (2003) 131:68-74. doi:10.1046/j.1365-2249.2003. 02020.x

208. Rüter J, Hoffmann T, Heiser U, Demuth H-U, Arck PC, Klapp BF, et al. The expression of T-cell surface antigens CTLA-4, CD26, and CD28 is modulated by inhibition of dipeptidylpeptidase IV (DPP IV, CD26) activity in murine stress-induced abortions. Cell Immunol (2002) 220:150-6. doi:10. 1016/S0008-8749(03)00028-5

209. Wrenger S, Faust J, Mrestani-Klaus C, Fengler A, Stöckel-Maschek A, Lorey $\mathrm{S}$, et al. Downregulation of T cell activation following inhibition of dipeptidyl peptidase IV/CD26 by the N-terminal part of the thromboxane A2 receptor. J Biol Chem (2000) 275:22180-6. doi:10.1074/jbc.M002338200

210. Wrenger S, Faust J, Mrestani-Klaus C, Brandt W, Thielitz A, Neubert K, et al. Non-substrate peptides influencing dipeptidyl peptidase IV/CD26 activity and immune cell function. Front Biosci (2008) 13:3194-201. doi:10.2741/2920

211. Mele D, Sampson J, Huber B. Th17 differentiation is the default program for DPP2-deficient T cell differentiation. Eur J Immunol (2011) 41:1583-93. doi:10.1002/eji.201041157.T

212. Odaka C, Mizuochi T, Shirasawa T, Morain P, Checler F. Murine T cells expressing high activity of prolyl endopeptidase are susceptible to activationinduced cell death. FEBS Lett (2002) 512:163-7. doi:10.1016/S0014-5793(02) 02249-4

213. Muscat C, Bertotto A, Agea E. Expression and functional role of 1F7 (CD26) antigen on peripheral blood and synovial fluid $\mathrm{T}$ cells in rheumatoid arthritis patients. Clin Exp Immunol (1994) 98:252-6. doi:10.1111/j.1365-2249.1994. tb06134.x

214. Gerli R, Muscat C, Bertotto A, Bistoni O, Agea E, Tognellini R, et al. CD26 surface molecule involvement in $\mathrm{T}$ cell activation and lymphokine synthesis in rheumatoid and other inflammatory synovitis. Clin Immunol Immunopathol (1996) 80:31-7. doi:10.1006/clin.1996.0091

215. Ellingsen T, Hornung N, Møller BK, Hjelm-Poulsen J, Stengaard-Pedersen $\mathrm{K}$. In active chronic rheumatoid arthritis, dipeptidyl peptidase IV density is increased on monocytes and CD4(+) T lymphocytes. Scand J Immunol (2007) 66:451-7. doi:10.1111/j.1365-3083.2007.01966.x

216. Busso N, Wagtmann N, Herling C, Chobaz-Péclat V, Bischof-Delaloye A, So A, et al. Circulating CD26 is negatively associated with inflammation in human and experimental arthritis. Am J Pathol (2005) 166:433-42. doi:10. 1016/S0002-9440(10)62266-3

217. Ulusoy H, Kamanli A, Ilhan N, Kuru O, Arslan S, Alkan G, et al. Serum levels of soluble CD26 and CD30 and their clinical significance in patients with rheumatoid arthritis. Rheumatol Int (2012) 32:3857-62. doi:10.1007/ s00296-011-2302-3

218. Buljevic S, Detel D, Pucar LB, Mihelic R, Madarevic T, Sestan B, et al. Levels of dipeptidyl peptidase IV/CD26 substrates neuropeptide $\mathrm{Y}$ and vasoactive intestinal peptide in rheumatoid arthritis patients. Rheumatol Int (2013) 33:2867-74. doi:10.1007/s00296-013-2823-Z

219. Gotoh H, Hagihara M, Nagatsu T, Iwata H, Miura T. Activities of dipeptidyl peptidase II and dipeptidyl peptidase IV in synovial fluid from patients with rheumatoid arthritis and osteoarthritis. Clin Chem (1989) 35:1016-8.
220. Kamori M, Hagihara M, Nagatsu T, Iwata H, Miura T. Activities of dipeptidyl peptidase II, dipeptidyl peptidase IV, prolyl endopeptidase, and collagenaselike peptidase in synovial membrane from patients with rheumatoid arthritis and osteoarthritis. Biochem Med Metab Biol (1991) 45:154-60. doi:10.1016/ 0885-4505(91)90016-E

221. Hagihara M, Ohhashi M, Nagatsu T. Activities of dipeptidyl peptidase II and dipeptidyl peptidase IV in mice with lupus erythematosus-like syndrome and in patients with lupus erythematosus and rheumatoid arthritis. Clin Chem (1987) 33:1463-5.

222. Yamasaki SC, Murari-do-Nascimento S, Silveira PF. Neutral aminopeptidase and dipeptidyl peptidase IV in the development of collagen II-induced arthritis. Regul Pept (2012) 173:47-54. doi:10.1016/j.regpep.2011.09.004

223. Bauer S, Jendro MC, Wadle A, Kleber S, Stenner F, Dinser R, et al. Fibroblast activation protein is expressed by rheumatoid myofibroblast-like synoviocytes. Arthritis Res Ther (2006) 8:R171. doi:10.1186/ar2080

224. Tanaka S, Murakami T, Nonaka N, Ohnuki T, Yamada M, Sugita T. Antiarthritic effects of the novel dipeptidyl peptidase IV inhibitors TMC-2A and TSL-225. Immunopharmacology (1998) 40:21-6. doi:10.1016/S0162-3109(98) 00014-9

225. Saito T, Ohnuma K, Suzuki H, Dang NH, Hatano R, Ninomiya H, et al. Polyarthropathy in type 2 diabetes patients treated with DPP4 inhibitors. Diabetes Res Clin Pract (2013) 102:e8-12. doi:10.1016/j.diabres.2013.07.010

226. Yokota K, Igaki N. Sitagliptin (DPP-4 inhibitor)-induced rheumatoid arthritis in type 2 diabetes mellitus: a case report. Intern Med (2012) 51:2041-4. doi:10. 2169/internalmedicine.51.7592

227. Sasaki T, Hiki Y, Nagumo S, Ikeda R, Kimura H, Yamashiro K, et al. Acute onset of rheumatoid arthritis associated with administration of a dipeptidyl peptidase-4 (DPP-4) inhibitor to patients with diabetes mellitus. Diabetol Int (2010) 1:90-2. doi:10.1007/s13340-010-0010-y

228. Hildebrandt M, Rose M, Rüter J, Salama A, Mönnikes H, Klapp BF. Dipeptidyl peptidase IV (DP IV, CD26) in patients with inflammatory bowel disease. Scand J Gastroenterol (2001) 36:1067-72. doi:10.1080/003655201750422675

229. Moran GW, O’Neill C, Padfield P, McLaughlin JT. Dipeptidyl peptidase-4 expression is reduced in Crohn's disease. Regul Pept (2012) 177:40-5. doi:10. 1016/j.regpep.2012.04.006

230. Rovedatti L, Di Sabatino A, Knowles CH, Sengupta N, Biancheri P, Corazza GR, et al. Fibroblast activation protein expression in Crohn's disease strictures. Inflamm Bowel Dis (2011) 17:1251-3. doi:10.1002/ibd.21446

231. Yazbeck R, Sulda ML, Howarth GS, Bleich A, Raber K, von Hörsten S, et al. Dipeptidyl peptidase expression during experimental colitis in mice. Inflamm Bowel Dis (2010) 16:1340-51. doi:10.1002/ibd.21241

232. Ban H, Bamba S, Imaeda H, Inatomi O, Kobori A, Sasaki M, et al. The DPP-IV inhibitor ER-319711 has a proliferative effect on the colonic epithelium and a minimal effect in the amelioration of colitis. Oncol Rep (2011) 25:1699-703. doi:10.3892/or.2011.1223

233. Reinhold D, Biton A, Pieper S, Lendeckel U, Faust J, Neubert K, et al. Dipeptidyl peptidase IV (DP IV, CD26) and aminopeptidase N (APN, CD13) as regulators of $\mathrm{T}$ cell function and targets of immunotherapy in CNS inflammation. Int Immunopharmacol (2006) 6:1935-42. doi:10.1016/j.intimp.2006.07.023

234. Yazbeck R, Howarth GS, Geier MS, Demuth H-U, Abbott CA. Inhibiting dipeptidyl peptidase activity partially ameliorates colitis in mice. Front Biosci (2008) 13:6850-8. doi:10.2741/3193

235. Iwaya H, Fujii N, Hagio M, Hara H, Ishizuka S. Contribution of dipeptidyl peptidase IV to the severity of dextran sulfate sodium-induced colitis in the early phase. Biosci Biotechnol Biochem (2013) 77:1461-6. doi:10.1271/bbb. 130105

236. Mimura S, Ando T, Ishiguro K, Maeda O, Watanabe O, Ujihara $\mathrm{M}$, et al. Dipeptidyl peptidase-4 inhibitor anagliptin facilitates restoration of dextran sulfate sodium-induced colitis. Scand J Gastroenterol (2013) 48:1152-9. doi:10. 3109/00365521.2013.832366

237. Yazbeck R, Howarth GS, Butler RN, Geier MS, Abbott CA. Biochemical and histological changes in the small intestine of mice with dextran sulfate sodium colitis. J Cell Physiol (2011) 226:3219-24. doi:10.1002/jcp.22682

238. Sakanaka T, Inoue T, Yorifuji N, Iguchi M, Fujiwara K, Narabayashi K, et al. The effects of a TGR5 agonist and a dipeptidyl peptidase IV inhibitor on dextran sulfate sodium-induced colitis in mice. J Gastroenterol Hepatol (2015) 30(Suppl 1):60-5. doi:10.1111/jgh.12740 
239. Penttinen A, Tenorio-Laranga J, Siikanen A, Morawski M, Rossner S, GarcíaHorsman JA. Prolyl oligopeptidase: a rising star on the stage of neuroinflammation research. CNS Neurol Disord Drug Targets (2011) 10:340-8. doi:10. 2174/187152711794653742

240. Constantinescu CS, Kamoun M, Dotti M, Farber RE, Galetta SL, Rostami A. A longitudinal study of the T cell activation marker CD26 in chronic progressive multiple sclerosis. J Neurol Sci (1995) 130:178-82. doi:10.1016/0022-510X(95) 00031-V

241. Narikawa K, Misu T, Fujihara K, Nakashima I, Sato S, Itoyama Y. Soluble CD26 and CD30 levels in CSF and sera of patients with relapsing neuromyelitis optica. J Neurol (2006) 253:111-3. doi:10.1007/s00415-005-0901-1

242. Hagihara M, Fujiwara M, Nagatsu T. Activities of dipeptidyl peptidases in BXSB mice and MRL/lpr mice with lupus erythematosus-like syndrome. Biochem Med Metab Biol (1989) 42:224-31. doi:10.1016/0885-4505(89) 90060- 1

243. Kobayashi H, Hosono O, Mimori T, Kawasaki H, Dang NH, Tanaka H, et al. Reduction of serum soluble CD26/dipeptidyl peptidase IV enzyme activity and its correlation with disease activity in systemic lupus erythematosus. J Rheumatol (2002) 29:1858-66.

244. Nzeusseu Toukap A, Galant C, Theate I, Maudoux AL, Lories RJ, Houssiau FA, et al. Identification of distinct gene expression profiles in the synovium of patients with systemic lupus erythematosus. Arthritis Rheum (2007) 56:1579-88. doi:10.1002/art.22578

245. Van Lingen RG, van de Kerkhof PC, Seyger MM, de Jong EM, van Rens DW, Poll MK, et al. CD26/dipeptidyl-peptidase IV in psoriatic skin: upregulation and topographical changes. Br J Dermatol (2008) 158:1264-72. doi:10.1111/j. 1365-2133.2008.08515.x

246. Van Lingen RG, Poll MK, Seyger MM, de Jong EM, van de Kerkhof PC, van Erp PE. Distribution of dipeptidyl-peptidase IV on keratinocytes in the margin zone of a psoriatic lesion: a comparison with hyperproliferation and aberrant differentiation markers. Arch Dermatol Res (2008) 300:561-7. doi:10.1007/ s00403-008-0862-1

247. Yıldırım FE, Karaduman A, Pinar A, Aksoy Y. CD26/dipeptidyl-peptidase IV and adenosine deaminase serum levels in psoriatic patients treated with cyclosporine, etanercept, and psoralen plus ultraviolet A phototherapy. Int J Dermatol (2011) 50:948-55. doi:10.1111/j.1365-4632.2010.04799.x

248. Miyagaki T, Sugaya M, Suga H, Morimura S, Kamata M, Ohmatsu H, et al. Serum soluble CD26 levels: diagnostic efficiency for atopic dermatitis, cutaneous T-cell lymphoma and psoriasis in combination with serum thymus and activation-regulated chemokine levels. J Eur Acad Dermatol Venereol (2013) 27:19-24. doi:10.1111/j.1468-3083.2011.04340.x

249. Bock O, Kreiselmeyer I, Mrowietz U. Expression of dipeptidyl-peptidase IV (CD26) on CD8+ T cells is significantly decreased in patients with psoriasis vulgaris and atopic dermatitis. Exp Dermatol (2001) 10:414-9. doi:10.1034/j. 1600-0625.2001.100604.x

250. Van Lingen RG, van de Kerkhof PC, de Jong EM, Seyger MM, Boezeman JB, van Erp PE. Reduced CD26bright expression of peripheral blood CD8+ Tcell subsets in psoriatic patients. Exp Dermatol (2008) 17:343-8. doi:10.1111/ j.1600-0625.2007.00650.x

251. Mas-Vidal A, Santos-Juanes J, Esteve-Martinez A, Caminal-Montero L, CotoSegura P. Psoriasiform eruption triggered by a dipeptidyl peptidase IV inhibitor. Australas J Dermatol (2012) 53:70-2. doi:10.1111/j.1440-0960.2011. 00783.x

252. Nishioka T, Shinohara M, Tanimoto N, Kumagai C, Hashimoto K. Sitagliptin, a dipeptidyl peptidase-IV inhibitor, improves psoriasis. Dermatology (2012) 224:20-1. doi:10.1159/000333358

253. Jialal I, Bajaj M. DPP-4 inhibitors and atherosclerosis: the promise. Atherosclerosis (2013) 227:224-5. doi:10.1016/j.atherosclerosis.2012.12.033

254. Buse JB, Ginsberg HN, Bakris GL, Clark NG, Costa F, Eckel R, et al. Primary prevention of cardiovascular diseases in people with diabetes mellitus: a scientific statement from the American Heart Association and the American Diabetes Association. Circulation (2007) 115:114-26. doi:10.1161/ CIRCULATIONAHA.106.179294

255. Terasaki M, Nagashima M, Watanabe T, Nohtomi K, Mori Y, Miyazaki A, et al. Effects of PKF275-055, a dipeptidyl peptidase-4 inhibitor, on the development of atherosclerotic lesions in apolipoprotein E-null mice. Metabolism (2012) 61:974-7. doi:10.1016/j.metabol.2011.11.011
256. Ervinna N, Mita T, Yasunari E, Azuma K, Tanaka R, Fujimura S, et al. Anagliptin, a DPP-4 inhibitor, suppresses proliferation of vascular smooth muscles and monocyte inflammatory reaction and attenuates atherosclerosis in male apo E-deficient mice. Endocrinology (2013) 154:1260-70. doi:10.1210/ en.2012-1855

257. Matsubara J, Sugiyama S, Akiyama E, Iwashita S, Kurokawa H, Ohba K, et al. Dipeptidyl peptidase-4 inhibitor, sitagliptin, improves endothelial dysfunction in association with its anti-inflammatory effects in patients with coronary artery disease and uncontrolled diabetes. Circ J (2013) 77:1337-44. doi:10. 1253/circj.CJ-12-1168

258. Vittone F, Liberman A, Vasic D, Ostertag R, Esser M, Walcher D, et al. Sitagliptin reduces plaque macrophage content and stabilises arteriosclerotic lesions in Apoe (-/-) mice. Diabetologia (2012) 55:2267-75. doi:10.1007/ s00125-012-2582-5

259. Terasaki M, Nagashima M, Nohtomi K, Kohashi K, Tomoyasu M, Sinmura $\mathrm{K}$, et al. Preventive effect of dipeptidyl peptidase- 4 inhibitor on atherosclerosis is mainly attributable to incretin's actions in nondiabetic and diabetic apolipoprotein E-null mice. PLoS One (2013) 8:e70933. doi:10.1371/journal. pone.0070933

260. Akita K, Isoda K, Shimada K, Daida H. Dipeptidyl-peptidase-4 inhibitor, alogliptin, attenuates arterial inflammation and neointimal formation after injury in low-density lipoprotein (LDL) receptor-deficient mice. J Am Heart Assoc (2015) 4:e001469-001469. doi:10.1161/JAHA.114.001469

261. Zheng TP, Yang F, Gao Y, Baskota A, Chen T, Tian HM, et al. Increased plasma DPP4 activities predict new-onset atherosclerosis in association with its proinflammatory effects in Chinese over a four year period: a prospective study. Atherosclerosis (2014) 235:619-24. doi:10.1016/j.atherosclerosis.2014. 05.956

262. Barbieri M, Rizzo MR, Marfella R, Boccardi V, Esposito A, Pansini A, et al. Decreased carotid atherosclerotic process by control of daily acute glucose fluctuations in diabetic patients treated by DPP-IV inhibitors. Atherosclerosis (2013) 227:349-54. doi:10.1016/j.atherosclerosis.2012.12.018

263. Kutoh E, Kaneoka N, Hirate M. Alogliptin: a new dipeptidyl peptidase4 inhibitor with potential anti-atherogenic properties. Endocr Res (2014) 40(2):88-96. doi:10.3109/07435800.2014.952743

264. Libby P. Inflammation and atherosclerosis. Circulation (2002) 105:1135-43. doi:10.1161/hc0902.104353

265. Hansson GK, Libby P. The immune response in atherosclerosis: a doubleedged sword. Nat Rev Immunol (2006) 6:508-19. doi:10.1038/nri1882

266. Matsubara J, Sugiyama S, Sugamura K, Nakamura T, Fujiwara Y, Akiyama E, et al. A dipeptidyl peptidase- 4 inhibitor, des-fluoro-sitagliptin, improves endothelial function and reduces atherosclerotic lesion formation in apolipoprotein E-deficient mice. J Am Coll Cardiol (2012) 59:265-76. doi:10.1016/j.jacc.2011.07.053

267. Wei D, Wang G, Tang C, Qiu J, Zhao J, Gregersen H, et al. Upregulation of SDF-1 is associated with atherosclerosis lesions induced by LDL concentration polarization. Ann Biomed Eng (2012) 40:1018-27. doi:10.1007/ s10439-011-0486-Z

268. Li L-X, Zhang X-F, Bai X, Tong Q. SDF-1 promotes ox-LDL induced vascular smooth muscle cell proliferation. Cell Biol Int (2013) 37:988-94. doi:10.1002/ cbin. 10126

269. Brokopp CE, Schoenauer R, Richards P, Bauer S, Lohmann C, Emmert MY, et al. Fibroblast activation protein is induced by inflammation and degrades type I collagen in thin-cap fibroatheromata. Eur Heart J (2011) 32:2713-22. doi:10.1093/eurheartj/ehq519

Conflict of Interest Statement: The authors declare that the research was conducted in the absence of any commercial or financial relationships that could be construed as a potential conflict of interest.

Copyright (C) 2015 Waumans, Baerts, Kehoe, Lambeir and De Meester. This is an open-access article distributed under the terms of the Creative Commons Attribution License (CC BY). The use, distribution or reproduction in other forums is permitted, provided the original author(s) or licensor are credited and that the original publication in this journal is cited, in accordance with accepted academic practice. No use, distribution or reproduction is permitted which does not comply with these terms. 